Prepared in cooperation with Colorado Springs City Engineering

\title{
Urban-Related Environmental Variables and Their Relation with Patterns in Biological Community Structure in the Fountain Creek Basin, Colorado, 2003-2005
}

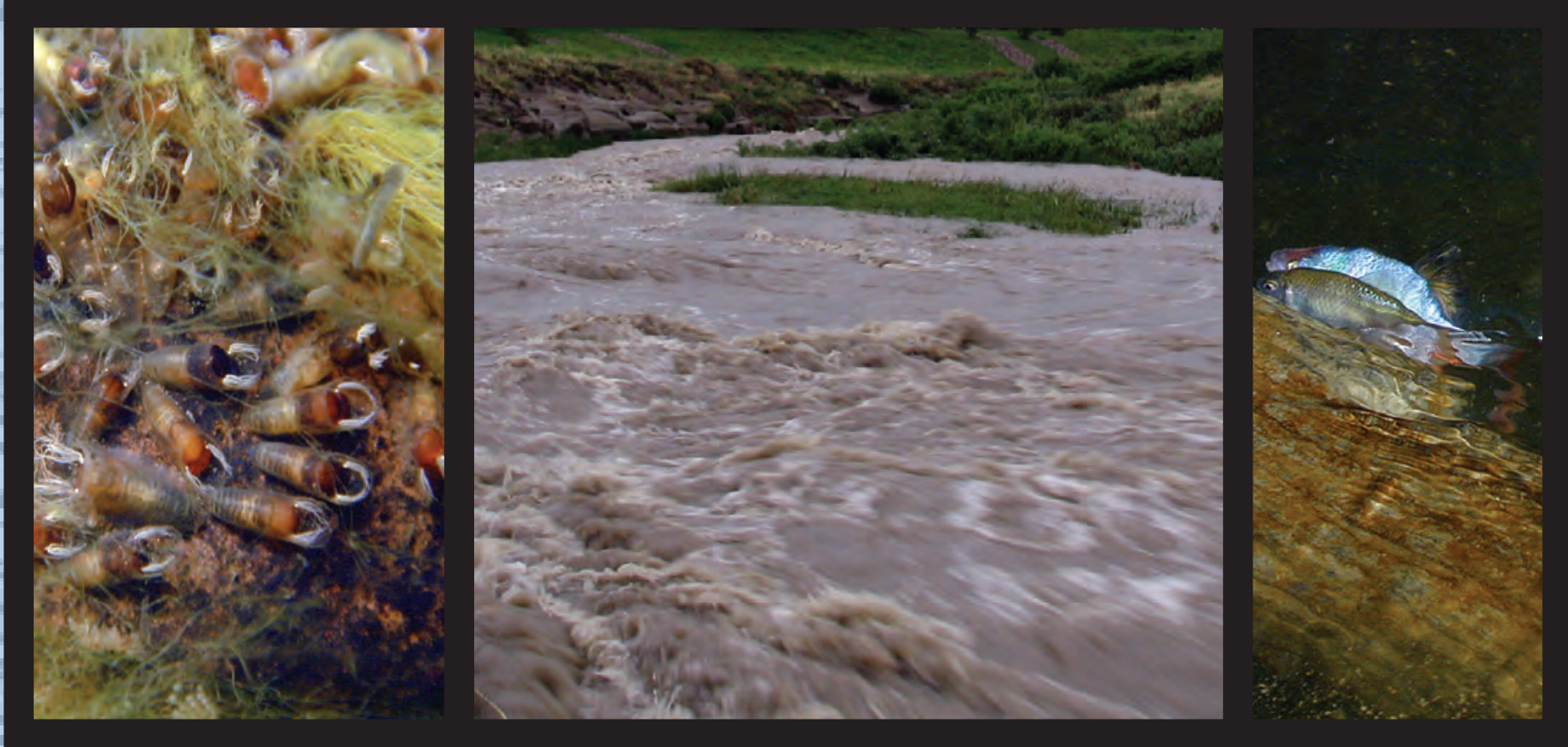

Scientific Investigations Report 2007-5225 
Cover photographs and credits (from left):

Pupal and larval blackflies (Simulium sp.) in riffle habitat. (Photograph by Robert Zuellig, U.S. Geological Survey)

Stormflow at Cottonwood Creek Tributary above Rangewood Drive, at Colorado Springs, Colorado. (Photograph by Robert Stogner, U.S. Geological Survey)

Male and female Red Shiner (Cyprinella lutrensis) exhibiting spawning behavior. (Photograph by Robert Zuellig, U.S. Geological Survey) 


\section{Urban-Related Environmental Variables and Their Relation with Patterns in Biological Community Structure in the Fountain Creek Basin, Colorado, 2003-2005}

By Robert E. Zuellig, James F. Bruce, Erin E. Evans, and Robert W. Stogner

Prepared in cooperation with Colorado Springs City Engineering

Scientific Investigations Report 2007-5225

U.S. Department of the Interior

U.S. Geological Survey 


\section{U.S. Department of the Interior DIRK KEMPTHORNE, Secretary}

\section{U.S. Geological Survey \\ Mark D. Myers, Director}

\section{U.S. Geological Survey, Reston, Virginia: 2008}

For product and ordering information:

World Wide Web: http://www.usgs.gov/pubprod

Telephone: 1-888-ASK-USGS

For more information on the USGS — the Federal source for science about the Earth, its natural and living resources, natural hazards, and the environment:

World Wide Web: http://www.usgs.gov

Telephone: 1-888-ASK-USGS

Any use of trade, product, or firm names is for descriptive purposes only and does not imply endorsement by the U.S. Government.

Although this report is in the public domain, permission must be secured from the individual copyright owners to reproduce any copyrighted materials contained within this report.

Suggested citation:

Zuellig, R.E., Bruce, J.F., Evans, E.E., and Stogner, R.W., 2008, Urban-related environmental variables and their relation with patterns in biological community structure in the Fountain Creek Basin, Colorado, 2003-2005: U.S. Geological Survey Scientific Investigations Report 2007-5225, 24 p. 


\section{Contents}

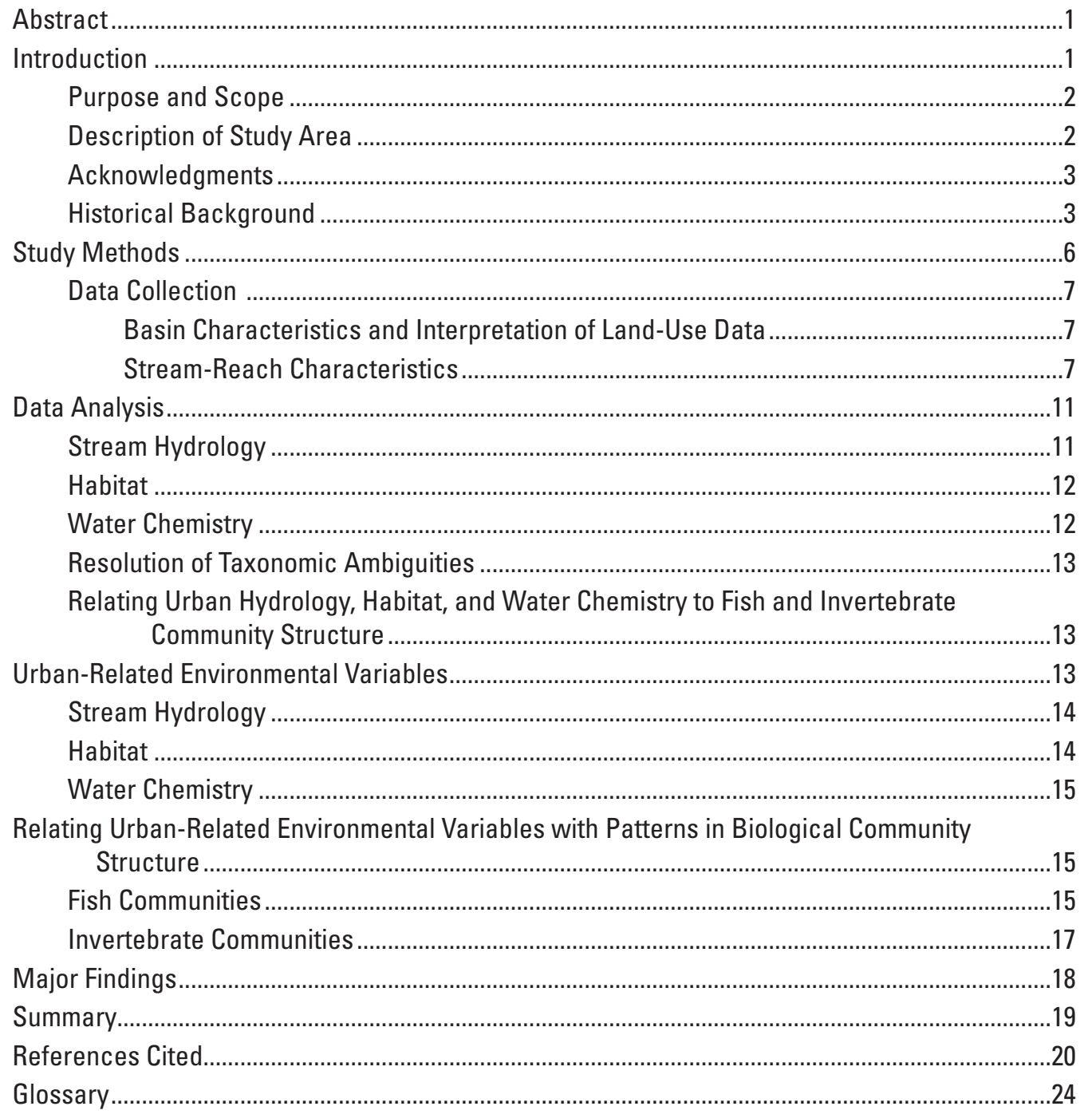




\section{Figures}

1. Map showing locations of stream segments and sampling sites in the Fountain Creek basin, Colorado, 2003-2005.

2. Conceptual model showing the primary urban-related environmental variables associated with stream ecology in the Fountain Creek basin, Colorado.

\section{Tables}

1. Description of sites and types of data collected in the Fountain Creek basin, Colorado, 2003-2005.

2. Basin and stream-reach habitat variables used to characterize selected sites in the Fountain Creek basin, Colorado, 2003-2005

3. Coefficients used to convert land use to impervious surface coverage in the Fountain Creek basin, Colorado, 2003-2005

4. Water-chemistry variables used to characterize selected sites in the Fountain Creek basin, Colorado, 2003-2005..

5. Hydrologic indices calculated to characterize the flow regimes from selected sites in the Fountain Creek basin, Colorado, 2003-2005

6. Correlation matrix showing Spearman's rho values relating impervious surface cover and eight environmental variables used in the exploratory multivariate analysis (BIO-ENV procedure)

7. Correlation coefficients associated with the best subsets of urban-related environmental variables describing biological community structure from the exploratory multivariate analysis (BIO-ENV procedure). 


\section{Conversion Factors and Datums}

\begin{tabular}{lcl}
\hline \multicolumn{1}{c}{ Multiply } & By & \multicolumn{1}{c}{ To obtain } \\
\hline inch (in) & Length & \\
inch (in) & $2.54 \times 10^{0}$ & centimeter $(\mathrm{cm})$ \\
inch (in) & $2.54 \times 10^{1}$ & millimeter $(\mathrm{mm})$ \\
foot (ft) & $2.54 \times 10^{4}$ & micrometer $\mu \mathrm{m})$ \\
mile (mi) & $3.048 \times 10^{-1}$ & meter $(\mathrm{m})$ \\
micrometer $(\mu \mathrm{m})$ & $1.609 \times 10^{0}$ & kilometer $(\mathrm{km})$ \\
\hline \multicolumn{3}{c}{ Flow rate } \\
\hline cubic foot per second $\left(\mathrm{ft}^{3} / \mathrm{s}\right)$ & $2.832 \times 10^{-2}$ & cubic meter per second $\left(\mathrm{m}^{3} / \mathrm{s}\right)$ \\
\hline
\end{tabular}

Temperature in degrees Celsius $\left({ }^{\circ} \mathrm{C}\right)$ may be converted to degrees Fahrenheit $\left({ }^{\circ} \mathrm{F}\right)$ as follows: ${ }^{\circ} \mathrm{F}=\left(1.8 x^{\circ} \mathrm{C}\right)+32$

Vertical coordinate information is referenced to the North American Vertical Datum of 1988 (NAVD 88).

Horizontal coordinate information is referenced to the North American Datum of 1983 (NAD 83).

Altitude, as used in this report, refers to distance above the vertical datum.

Specific conductance is given in microsiemens per centimeter at 25 degrees Celsius $(\mu \mathrm{S} / \mathrm{cm}$ at $\left.25^{\circ} \mathrm{C}\right)$.

Concentrations of chemical constituents in water are given either in milligrams per liter (mg/L) or micrograms per liter $(\mu \mathrm{g} / \mathrm{L})$. 


\section{Abbreviations}

$\begin{array}{ll}\text { BIO-ENV } & \text { exploratory multivariate analysis } \\ \text { CDOW } & \text { Colorado Division of Wildlife } \\ \text { CDPHE } & \begin{array}{l}\text { Colorado Department of Public Health and Environment } \\ \text { direct current }\end{array} \\ \text { DC } & \text { hydrologic indices } \\ \text { HIs } & \text { Hydrologic Index Tool } \\ \text { HIT } & \text { Invertebrate Data Analysis System } \\ \text { IDAS } & \text { impervious surface coverage } \\ \text { ISC } & \text { nonmetric multidimensional scaling } \\ \text { MDS } & \text { National Water-Quality Assessment Program } \\ \text { NAWQA } & \text { National Water Information System } \\ \text { NWIS } & \text { National Water Quality Laboratory } \\ \text { NWQL } & \text { polycyclic aromatic hydrocarbons } \\ \text { PAHs } & \text { Plymouth Routines in Multivariate Ecological Research } \\ \text { PRIMER } & \text { qualitative multihabitat } \\ \text { QMH } & \text { Rapid Bioassessment Protocols } \\ \text { RBP } & \text { richest targeted habitat } \\ \text { RTH } & \text { semipermeable membrane devices } \\ \text { SPMDs } & \text { U.S. Environmental Protection Agency } \\ \text { USEPA } & \text { U.S. Geological Survey } \\ \text { USGS } & \text { wastewater-treatment facility } \\ \text { WWTF } & \text { Tat }\end{array}$




\title{
Urban-Related Environmental Variables and Their Relation with Patterns in Biological Community Structure in the Fountain Creek Basin, Colorado, 2003-2005
}

\author{
By Robert E. Zuellig, James F. Bruce, Erin E. Evans, and Robert W. Stogner
}

\begin{abstract}
In 2003, the U.S. Geological Survey, in cooperation with Colorado Springs City Engineering began a study to evaluate the influence of urbanization on stream ecosystems. To accomplish this task, invertebrate, fish, stream discharge, habitat, water-chemistry, and land-use data were collected from 13 sites in the Fountain Creek basin from 2003 to 2005. The Hydrologic Index Tool was used to calculate hydrologic indices known to be related to urbanization. Response of stream hydrology to urbanization was evident among hydrologic variables that described stormflow. These indices included one measurement of high-flow magnitude, two measurements of high-flow frequency, and one measurement of stream flashiness. Habitat and selected nonstormflow water chemistry were characterized at each site. Land-use data were converted to estimates of impervious surface cover and used as the measure of urbanization annually. Correlation analysis (Spearman's rho) was used to identify a suite of nonredundant streamflow, habitat, and water-chemistry variables that were strongly associated (rho $>0.6$ ) with impervious surface cover but not strongly related to elevation $($ rho $<0.60)$.

An exploratory multivariate analysis (BIO-ENV, PRIMER ver 6.1, Plymouth, UK) was used to create subsets of eight urban-related environmental variables that described patterns in biological community structure. The strongest and most parsimonious subset of variables describing patterns in invertebrate community structure included high flood pulse count, lower bank capacity, and nutrients. Several other combinations of environmental variables resulted in competing subsets, but these subsets always included the three variables found in the most parsimonious list.

This study found that patterns in invertebrate community structure from 2003 to 2005 in the Fountain Creek basin were associated with a variety of environmental characteristics influenced by urbanization. These patterns were explained by a combination of hydrologic, habitat, and water-chemistry variables. Fish community structure showed weaker links
\end{abstract}

between urban-related environmental variables and biological patterns. A conceptual model was developed that showed the influence of urban-related environmental variables and their relation to fish and invertebrate assemblages. This model should prove helpful in guiding future studies on the impacts of urbanization on aquatic systems. Long-term monitoring efforts may be needed in other drainages along the Front Range of Colorado to link urban-related variables to aquatic communities in transition zone streams.

\section{Introduction}

Anthropogenic influences on the landscape occur worldwide and nowhere else is this more apparent than in the urban environment. Land-use changes accompanying urbanization are often linked to the degradation of stream ecosystems (Klein, 1979; Kennen, 1999; Paul and Meyer, 2001; Roy and others, 2003; Roy and others, 2005). Recently, the U.S. Environmental Protection Agency (USEPA) reported that urbanization was ranked third as a leading source of river impairment behind agriculture and hydrologic modification (U.S. Environmental Protection Agency, 2000).

As urban areas develop, land-cover characteristics change and the amount of impervious surface coverage (ISC) increases. Such changes alter surface- and ground-water hydrology, resulting in increased runoff rates, decreased base flow, increased peak flows (Knighton, 1998; Dunne and Leopold, 1978; Leopold 1968), reduced infiltration rates, and pollutant-filtering efficiency (Riordan and others, 1978). In some situations, reductions in base flow can be offset by lawn irrigation, leaky infrastructure, and discharge from wastewatertreatment facilities (WWTF) (Hirsch and others, 1990; Roy and others, 2005).

Increased frequency of flooding and peak discharge during rain events can cause severe erosion of a stream channel. Flooding, erosion, and stream bank instability deteriorate the natural values of streams and damage adjacent properties. 
In an attempt to protect property owners from flooding or poor drainage structural solutions are often used that confine, deepen and straighten stream channels (Klein, 1979; Dunne and Leopold 1978). These structures can decrease stream habitat complexity by destroying pool-and-riffle sequences, removing woody debris and riparian vegetation, and altering particle-size structure of bottom substrate (Burton and Pitt, 2002; Pizzuto and others, 2000). Changes in stream hydrology, water chemistry, and physical habitat associated with changes in ISC often results in altered aquatic communities and biological processes (Roy and others, 2005; Roy and others, 2003; Paul and Meyer, 2001).

Increased urban runoff can lead to substantial changes in water quality from point and nonpoint sources (Sprague and others, 2006; Edelmann and others, 2002; Pitt and others, 1995; House and others, 1993). Typical urban contaminants that pollute streams include nutrients, metals, bacteria, sediments, pesticides, hydrocarbons, analgesics, antibiotics, and endocrine disruptors (Pitt and others, 1995; House and others, 1993; Kolpin and others, 2002). Because of decreased base flow, concentrations of some of these contaminants also may be higher during dry periods due to decreased dilution capacity (Burton and Pitt, 2002). Many of these contaminants have been associated with undesirable changes in aquatic communities (for example, see Waters, 1995; LeBlanc and others, 1997; McMurry and others, 1998; Fitzgerald and others, 1999; Burton and Pitt, 2002; Thorpe and others, 2001; Schreurs and others, 2004).

The influence of urbanization on stream discharge (streamflow), habitat, and aquatic communities is an emerging issue of local, state, and national importance. Although consistent responses in urban streams have been identified in the eastern part of the United States, few studies have been conducted in the semi-arid western states. Rapid urban growth and development are occurring in many of these states, including along the Front Range of Colorado. To address these concerns, the U.S. Geological Survey (USGS), in cooperation with Colorado Springs City Engineering, began a study of the Fountain Creek basin in 2003 to evaluate the influence of urbanization on stream hydrology, habitat, water chemistry, and aquatic communities.

\section{Purpose and Scope}

This report evaluates how urbanization (measured as impervious surface coverage, ISC) and hydrology, habitat, and water chemistry relate to changes in fish and benthic invertebrate community structure at 13 streamflow-gaging stations (fig. 1) in the Fountain Creek basin from 2003 to 2005. The original scope of this study was to evaluate biological responses influenced by ISC (urbanization) between and within several different site types grouped by similarities in environmental characteristics, such as discharge, percent ISC, geomorphology, streambed substrate, canopy opening, and spatial relation to the Las Vegas St. WWTF in Colorado Springs (fig. 1). However, precipitation data needed to simulate streamflow at 11 additional sites were not available as intended. Consequently, the scope of this report is limited to evaluating data for the 13 sites with permanent streamflow gages (fig. 1), resulting in a data set that is highly auto-correlated in space and time and has limited statistical analysis options. Therefore, results of this study were interpreted with caution.

Habitat, fish, and invertebrate data evaluated in this report are available upon request from the USGS Colorado Water Science Center (Pueblo, Colorado office). Stream discharge and water- chemistry data can be obtained on the Web at http://waterdata.usgs.gov/co/nwis (search by USGS station number, fig. 1; table 1).

\section{Description of Study Area}

The Fountain Creek basin (fig. 1) has a drainage area of about $926 \mathrm{mi}^{2}$, and elevation ranges from about 4,700 $\mathrm{ft}$ at the confluence with the Arkansas River to $14,109 \mathrm{ft}$ at the summit of Pikes Peak. There are two major physiographic landforms within the area-the Front Range and the Colorado Piedmont (Hansen and Crosby, 1982), which correspond to two Level III ecoregions - the Southern Rockies and the Southwestern Tablelands (Omernik, 1987). The Front Range, which comprises the western one-third of the study area, is underlain by granite. Soils in this area are well drained and occur on steep slopes (Larsen, 1981; von Guerard, 1989). The Colorado Piedmont, which comprises the remaining eastern two-thirds of the area, abuts the base of the Rampart Range, which is a sub-range of the Front Range, and is underlain by sandstone, shale, alluvial, and windblown deposits. Soils in this area are generally sandy and well drained with more gentle slopes (Larsen, 1981; von Guerard, 1989). The soils and geologic formations in the Colorado Piedmont are readily erodible. Larsen (1981) and von Guerard (1989) thoroughly describe the soils and geology of the study area.

Fountain and Monument Creeks are the two main streams within the study area and are located in the transition of the two distinctive physiographic landforms. To facilitate the general physical description of Fountain Creek, three segments were defined: the upper, middle, and lower segments (fig. 1).

The upper segment begins at the headwaters near Woodland Park and continues downstream to the confluence with Monument Creek. Fountain Creek is an intermittent stream for approximately the first half of the upper segment and it becomes a perennial stream near the town of Green Mountain Falls. Fountain Creek flows southeastward through a deeply incised canyon through Manitou Springs to the confluence with Monument Creek. The stream channel upstream from Manitou Springs meanders little due to the constraints of a major highway, is characterized by riffles and pools, and has bed material that ranges from sand and gravels to cobbles and boulders. From Manitou Springs, Fountain Creek flows through alluvial terraces into a wide alluvial valley; the channel meanders less due to intermittent channelization, consists 
of pools, riffles, and runs, and has bed material that is predominantly sand, gravel, and cobble.

The middle segment begins at the confluence of Monument Creek and continues downstream to USGS station number 07105800 (fig. 1). In the middle segment, the channel becomes braided, stream segments have been channelized, streamflow is dominated by runs with few pools, and the streambanks are intermittently lined with concrete, and other manmade materials. The bed material is variable; some stream reaches have predominantly cobble substrate, some are scoured to bedrock, and others are a mixture of sand, gravel, and cobble.

The lower segment of Fountain Creek begins immediately downstream from USGS station number 07105800 (fig. 1) and continues to the confluence of the Arkansas River in Pueblo, Colorado. The channel in the lower segment meanders more, is wider, and is often braided. Streamflow is composed almost exclusively of runs. Several reaches have been channelized for irrigation and transportation purposes. The streambed material in this segment is almost exclusively composed of sand and gravel. Large woody debris piles accumulate infrequently in the channel and along the banks. However, these debris piles are not stable and frequently are moved or buried during high flows. Periods of little or no flow were not unusual along the lower segment prior to about 1980, especially during the latesummer irrigation season (Stogner, 2000).

Monument Creek, the main tributary to Fountain Creek, is a perennial stream that originates in the Rampart Range and flows eastward toward Palmer Lake, then south to Colorado Springs. Upstream from the confluence with Cottonwood Creek, Monument Creek is meandering, has pools, riffles, and runs, and has bed material consisting of sand, gravel, and cobble. Downstream from the confluence with Cottonwood Creek, the channel becomes braided, sand and small gravel compose the streambed along with manmade materials, the stream banks are intermittently lined with concrete, and extensive channelization has occurred. The braided channel conditions occur intermittently throughout the remaining length of channel with few areas of pools and riffles.

\section{Acknowledgments}

Gary Dowler, Dan Frankowski, and Londell Ackley of the Colorado Division of Wildlife (CDOW) provided backpack electrofishing equipment and contributed greatly to the fish-sampling efforts. Thanks to Lisa Ross, Colorado Springs City Engineering, for her support of the program. Thanks also to Colorado Springs Utilities for their support. Gary Dowler and Nicole Vieira (CDOW) provided a thoughtful review and comments that improved the report. Thanks to Joel Mackey, Colorado Springs City Engineering, for providing land-use data. The authors also thank those who assisted with the data collection, including USGS employees Wade J. Walker, Mark Salay, John Ragulsky, and all USGS hydrographers that collected, compiled, and analyzed streamflow measurement data.

\section{Historical Background}

Streamflow and Habitat. By the mid-1800s, human alteration of stream habitats, natural flow regimes, and aquatic biota had occurred in streams and tributaries near the transition from plains to mountains along the Front Range of Colorado (Fausch and Bestgen, 1997 and citations within). Although never formally defined, this transition zone likely varies in width depending on local topography. It is thought to be approximately 20 miles wide and situated between plains and montane habitats at elevations usually less than 7,000 ft and greater than 4,000 ft (Fausch and Bestgen, 1997; Nesler and others, 1999). Historical accounts (Fausch and Bestgen, 1997 and citation within) from the 1840s of the physical habitat attributes from transition zone and plains streams of eastern Colorado indicate that several changes had occurred with minimal documentation. Chief among the physical habitat modifications to plains streams in Colorado during this time was channel widening, which was exacerbated by drought in the 1930s, increased sinuosity and pool frequency, and riparian encroachment by woody vegetation (Fausch and Bestgen, 1997 and citations within). In addition, changes to transition zone streams included a streambed substrate from cobble and gravel to less coarse particles and increased turbidity (Fausch and Bestgen, 1997).

Documented hydrologic modifications to plains and transition zone streams began as early as 1840 with the construction of small ditches for agriculture and mining (Fausch and Bestgen, 1997 and citations within). Subsequently, large canals were constructed as the need for irrigation grew (1860-1885), and later (1885-1940s) large mainstem reservoirs were constructed to store snowmelt runoff and control flooding. The most recent hydrologic modifications (1940s-present) include reservoir construction that provided additional water for agriculture and municipal water use, and ground-water withdrawals that has decreased base flow (Cross and Moss, 1987). In addition, transmountain water diversions, expansion of wastewater-treatment facility (WWTF) discharge, and urbanization have resulted in increased base flow.

The modifications briefly described above have changed the hydrologic and physical characteristics of plains streams and transition zone streams in Colorado. In snowmelt-driven systems, maximum flows related to snowmelt runoff have been reduced in many plains streams whereas base flow has increased in basins with mainstem reservoirs (Nadler and Schumm, 1981). However, in some plains streams groundwater withdrawals, irrigation canals, and off channel ponds have decreased base flow and in some instances completely dewatered channels (Cross and Moss, 1987). In Fountain Creek, base flow above the Las Vegas St. WWTF in Colorado Springs (fig. 1) is primarily sustained by ground-water discharge, but downstream from the WWTF, base flow is composed predominantly of WWTF discharge (Edelmann and others, 2002). A substantial increase in base flow was evident in the lower reaches of Fountain Creek after 1980 when trans-mountain return flows were not available for irrigation 


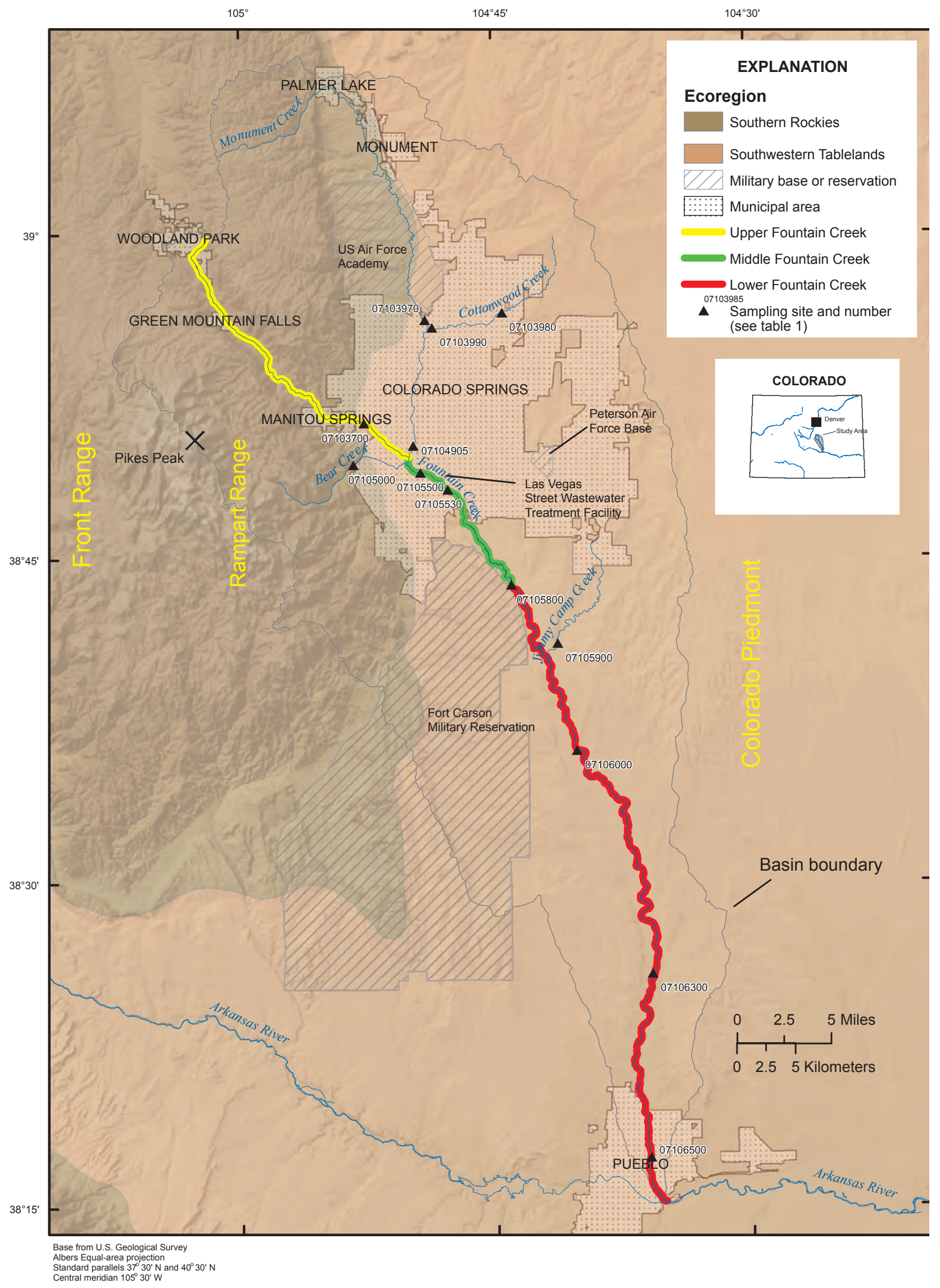

Figure 1. Map showing locations of stream segments and sampling sites in the Fountain Creek basin, Colorado, 2003-2005. 
Table 1. Description of sites and types of data collected in the Fountain Creek basin, Colorado, 2003-2005.

[USGS, U.S. Geological Survey; ID, identification; NAVD 88, North American Vertical Datum of 1988; ft, feet; mi², square miles; ISC, impervious surface cover; X, collected; --, not collected]

\begin{tabular}{|c|c|c|c|c|c|c|c|c|c|c|}
\hline $\begin{array}{l}\text { USGS } \\
\text { station } \\
\text { number }\end{array}$ & Station name & $\begin{array}{l}\text { Site } \\
\text { ID }\end{array}$ & $\begin{array}{c}\text { Elevation } \\
\text { NAVD } 88 \\
\text { (ft) }\end{array}$ & $\begin{array}{l}\text { Drainage } \\
\text { area } \\
\left(\mathrm{mi}^{2}\right)\end{array}$ & $\begin{array}{l}\text { Mean } \\
\text { percent } \\
\text { ISC }\end{array}$ & $\begin{array}{l}\text { Stream- } \\
\text { flow } \\
\text { dis- } \\
\text { charge }\end{array}$ & Habitat & $\begin{array}{l}\text { Chem- } \\
\text { istry }\end{array}$ & Fish & $\begin{array}{l}\text { Inverte- } \\
\text { brates }\end{array}$ \\
\hline 07103700 & $\begin{array}{l}\text { Fountain Creek near } \\
\text { Colorado Springs, } \\
\text { Colo. }\end{array}$ & $\mathrm{FC} 1$ & 6,110 & 103 & 8.9 & $\mathrm{X}$ & $\mathrm{X}$ & $\mathrm{X}$ & $\mathrm{X}$ & $\mathrm{X}$ \\
\hline 07103970 & $\begin{array}{l}\text { Monument Creek } \\
\text { above Woodmen } \\
\text { Road at Colorado } \\
\text { Springs, Colo. }\end{array}$ & $\mathrm{MC} 1$ & 6,270 & 181 & 11 & $\mathrm{X}$ & $\mathrm{X}$ & $\mathrm{X}$ & $\mathrm{X}$ & $\mathrm{X}$ \\
\hline 07103980 & $\begin{array}{l}\text { Cottonwood Creek at } \\
\text { Woodmen Road near } \\
\text { Colorado Springs, } \\
\text { Colo. }\end{array}$ & $\mathrm{CC} 1$ & 6,680 & 10.3 & 14.4 & $\mathrm{X}$ & $\mathrm{X}$ & $\mathrm{X}$ & -- & $\mathrm{X}$ \\
\hline 07103990 & $\begin{array}{l}\text { Cottonwood Creek at } \\
\text { Mouth at Pikeview, } \\
\text { Colo. }\end{array}$ & $\mathrm{CC} 2$ & 6,265 & 18.7 & 23 & $\mathrm{X}$ & $\mathrm{X}$ & $\mathrm{X}$ & -- & $\mathrm{X}$ \\
\hline 07104905 & $\begin{array}{l}\text { Monument Creek at } \\
\text { Bijou Street at Colo- } \\
\text { rado Springs, Colo. }\end{array}$ & MC2 & 5,980 & 235 & 14.2 & $\mathrm{X}$ & $\mathrm{X}$ & $\mathrm{X}$ & $\mathrm{X}$ & $\mathrm{X}$ \\
\hline 07105000 & $\begin{array}{l}\text { Bear Creek near Colo- } \\
\text { rado Springs, Colo. }\end{array}$ & $\mathrm{BC}$ & 6,520 & 6.89 & 2.3 & $\mathrm{X}$ & $\mathrm{X}$ & $\mathrm{X}$ & -- & $\mathrm{X}$ \\
\hline 07105500 & $\begin{array}{l}\text { Fountain Creek at } \\
\text { Colorado Springs, } \\
\text { Colo. }\end{array}$ & $\mathrm{FC} 2$ & 5,900 & 392 & 12.4 & $\mathrm{X}$ & $\mathrm{X}$ & $\mathrm{X}$ & $\mathrm{X}$ & $\mathrm{X}$ \\
\hline 07105530 & $\begin{array}{l}\text { Fountain Creek below } \\
\text { Janitell Road below } \\
\text { Colorado Springs, } \\
\text { Colo. }\end{array}$ & FC3 & 5,840 & 413 & 14.1 & $\mathrm{X}$ & $\mathrm{X}$ & $\mathrm{X}$ & $\mathrm{X}$ & $\mathrm{X}$ \\
\hline 07105800 & $\begin{array}{c}\text { Fountain Creek at } \\
\text { Security, Colo. }\end{array}$ & FC4 & 5,640 & 495 & 15.7 & $\mathrm{X}$ & $\mathrm{X}$ & $\mathrm{X}$ & $\mathrm{X}$ & $\mathrm{X}$ \\
\hline 07105900 & $\begin{array}{l}\text { Jimmy Camp Creek at } \\
\text { Fountain, Colo. }\end{array}$ & $\mathrm{JC}$ & 5,530 & 65.6 & 8.5 & $\mathrm{X}$ & $\mathrm{X}$ & $\mathrm{X}$ & -- & $\mathrm{X}$ \\
\hline 07106000 & $\begin{array}{l}\text { Fountain Creek near } \\
\text { Fountain, Colo. }\end{array}$ & FC5 & 5,355 & 681 & 14.9 & $\mathrm{X}$ & $\mathrm{X}$ & $\mathrm{X}$ & $\mathrm{X}$ & $\mathrm{X}$ \\
\hline 07106300 & $\begin{array}{l}\text { Fountain Creek near } \\
\text { Pinon, Colo. }\end{array}$ & FC6 & 4,990 & 849 & 12.5 & $\mathrm{X}$ & $\mathrm{X}$ & $\mathrm{X}$ & $\mathrm{X}$ & $\mathrm{X}$ \\
\hline 07106500 & $\begin{array}{l}\text { Fountain Creek at } \\
\text { Pueblo, Colo. }\end{array}$ & FC7 & 4,705 & 926 & 12 & $\mathrm{X}$ & $\mathrm{X}$ & $\mathrm{X}$ & $\mathrm{X}$ & $\mathrm{X}$ \\
\hline
\end{tabular}

${ }^{1}$ See figure 1. 
withdrawals (Stogner, 2000). Additionally, some historically ephemeral tributaries to Monument and Fountain Creeks may have become perennial with small base flow (Edelmann and others, 2002).

Fish Communities. Prior to 1900, fish had been collected from only 12 sites in the plains portion of Colorado (Fausch and Bestgen, 1997). Seven of these collections were from transition zone streams in the Arkansas River drainage near the cities of Canon City (about 33 mi northwest of Pueblo), Colorado Springs, and Pueblo. The other five collections were from transition zone and montane sites near Denver in the South Platte basin. Basin-wide fish surveys in the plains portion of the Arkansas River drainage, including Fountain Creek, did not occur until after 1958 (Fausch and Bestgen, 1997). Later, two comprehensive surveys of the plains portion of the Arkansas River basin were conducted by the Colorado Division of Wildlife (CDOW) (Loeffler and others, 1982; Nesler and others, 1999). Nesler and others (1999) made comparisons and described trends between the Loeffler and others (1982) and Nesler and others (1999) surveys. No differences in the number of native fish present were found in the Arkansas River basin between the two inventories. Although no differences in native fish presence were found between these inventories, the data allowed only for basin-wide assessments for the entire Arkansas River drainage. Such coarse-level comparisons provided little information regarding local changes in fish community dynamics that have likely occurred in plains streams and transition zone streams at smaller scales as changes in land cover associated with urbanization, hydrology, and habitat occurred.

Because the distribution of fishes in the Arkansas River basin was not documented until well after major changes in hydrology and habitat had occurred, how current patterns of fish distribution are related to historical conditions cannot be interpreted definitively. Fausch and Bestgen (1997) used literature accounts, museum records, and unpublished data to determine that there are likely 20 fish species native to the Arkansas River basin in Colorado. Of these 20 native species (see Table 6.1 in Fausch and Bestgen, 1997) a conservative estimate of 16 species could have occurred in the plains portion of the transition zone of the Fountain Creek basin. Of the four species not likely found in these segments of Fountain Creek, three are mainly associated with big rivers: plains minnow (Hybognathus placitus), speckled chub (Macrohybopsis aestivalis), and Arkansas River shiner (Notropis girardi). The fourth native species, the greenback cutthroat trout (Oncorhynchus clarki stomias), is a cold-water species and likely never persisted in the warmer waters of lower Fountain Creek.

During the two most recent inventories, Loeffler and others (1982) collected 11 native species while Nesler and others (1999) collected only 9 from Fountain Creek sites; however, sampling efficiency information associated with these data-collection efforts is unavailable to make a comparative assessment. Currently (2007), there are three state-listed and one federally-listed species in the Fountain Creek basin: southern redbelly dace (Phoxinus erythrogaster) which is state endangered, Arkansas darter (Etheostoma cragini) which is state threatened, flathead chub (Platygobio gracilis) which is a state species of concern, and greenback cutthroat trout which is federally threatened.

Invertebrate Communities. To date, no systematic survey of the Colorado aquatic insect fauna has focused on plains streams. There are only sporadic early records of aquatic invertebrates from plains streams, mostly from the South Platte River basin where several species apparently have been extirpated locally (Edmunds and McCafferty, 1984; McCafferty and others, 1993; Cordeiro, 1999; Kondratieff and Baumann, 2002, Zuellig and others, 2006).

Although there is little information about historic or current aquatic invertebrate species distribution in the Fountain Creek basin and most other plains streams of Colorado, there have been a few biomonitoring studies conducted in the Fountain Creek basin since the late 1980s. For example, von Guerard (1989) studied the effects of sediment-transport on aquatic invertebrates and sediment-transport characteristics in the Fountain Creek basin. In that study it was determined that mayflies, stoneflies, and caddisflies were more abundant at sites where the streambed was not influenced by aggradation and deposition. Additionally, median diameter of streambed material and flooding prior to invertebrate sampling explained most of the variation in invertebrate densities (at the genus or family level taxonomy). Additionally, von Guerard (1989) found that small to moderate streamflows were capable of transporting the majority of all streambed particle-size classes in Fountain and Monument Creeks. Bruce (2002) also found that substrate particle-size accounted for most of the variation in invertebrate community structure among sites in the Fountain Creek basin.

\section{Study Methods}

Thirteen sites were selected to represent varying environmental conditions found in the Fountain Creek basin to investigate the overall influence of urbanization (that is, ISC) on stream hydrology and its effect on habitat, water chemistry, and biological communities (fig. 1). Environmental (ISC and habitat) and biological (fish and invertebrates) data were collected once annually at respective sites from 2003 to 2005 (table 1). Streamflow was measured continuously at these sites, and selected water chemistry was collected 3-6 times annually during the study period. Each site was equipped with telemetry for the processing of daily real-time streamflow data. All data types collected at each site are listed in table 1, and can be requested from the USGS Colorado Water Science Center (Pueblo, Colorado office). Data were analyzed using descriptive statistics, such as Spearman rank correlation and exploratory nonparametric multivariate routines. Results of this study can help direct approaches of future investigations in the Fountain Creek basin. 


\section{Data Collection}

\section{Basin Characteristics and Interpretation of Land-Use Data}

For each site, 10 basin characteristics were derived from data consisting of mapped polygons of land use provided by the city of Colorado Springs (table 2). USGS topographic maps (U.S. Geological Survey, 1974) were used to estimate land uses and their corresponding area for approximately 30 percent of the total area of the lower segment of Fountain Creek because the city of Colorado Springs data did not include the entire Fountain Creek basin. These data provide information on the upstream influences and hydrologic constraints at a site. Additionally, land use and ISC were estimated annually for each site.

Land uses in the Fountain Creek basin include undeveloped land, agriculture, military reservations and airports, residential, commercial, industrial, and streets and easements. Estimates of ISC associated with different land uses were derived by applying coefficients to the summed area of the various land uses from the mapped polygons and interpolated from the USGS maps. The coefficients were adapted from Arnold and Gibbons (1996) and Pikes Peak Area Council of Governments (2005). The distribution of coefficients is listed in table 3 .

\section{Stream-Reach Characteristics}

Stream hydrology, habitat, selected water chemistry, and aquatic community structure were quantified at each site using established protocols. Methods used to collect these data are briefly described below.

Hydrology. Instantaneous stream discharge ( $\left.\mathrm{ft}^{3} / \mathrm{s}\right)$ was measured and mean daily stream discharge was computed in accordance with standard USGS procedures described by Rantz and others (1982). Measurements of instantaneous stream discharge were made throughout the study period in the vicinity of the USGS streamgages at cross-sections that had the most even distribution of streamflow. These measurements of stream discharge were used to develop site-specific stage-discharge relations (rating curves) that were then used to compute continuous discharge data from the stage record associated with the 13 USGS surface-water gages. Mean daily discharge was acquired from USGS streamgage records (Crowfoot and others, 2003-2005).

Habitat. At each site, 33 quantitative stream-reach characteristics (table 2) were measured using standardized USGS procedures (Meador and others, 1993) after biological sampling each year. In brief, reach length was defined as 20 times the mean wetted width (range 100 to $300 \mathrm{~m}$ [328 to $984 \mathrm{ft}$ ]). The length of each geomorphic channel unit (run, riffle, pool) was measured, and a pebble count at approximately 100 points along the reach was used to characterize three streambed and bank substrate compositions (Wolman, 1954) (table 2). Mea- surements of instream habitat were made along six equally spaced transects perpendicular to streamflow along each reach. At each transect, wetted channel width, streambed width, bankfull channel width, bank angle and height, stream depth, and current velocity were measured. Additionally, embeddedness was estimated along each transect. Froude number was calculated for each reach using stream depth and current velocity measurements. Riparian and bank vegetation characteristics as well as canopy opening also were recorded.

Twelve qualitative habitat variables (table 2) were evaluated during the invertebrate sampling site visits using the rapid bioassessment protocols (RBP) developed by Barbour and others (1997). In general, RBP attributes are separated into three categories: primary, secondary, and tertiary. The primary attributes (scored 0-20) characterize instream habitat and likely have the greatest direct influence on biological community structure. Secondary attributes (scored 0-15) characterize channel morphology, and tertiary attributes (scored 0-10) characterize bank structure and riparian areas. For each reach, the scores for each attribute were summed to derive a single numeric RBP value ranging from 0 to180 (unitless).

Water Chemistry. Routine water-chemistry samples during nonstormflow conditions were collected in June and September, bracketing the biological sampling using standard equipment with width- and depth-integrating techniques. At the time of sampling, field measurements were made for dissolved oxygen, $\mathrm{pH}$, specific conductance, and water temperature (table 4). All samples were collected, processed, and preserved in the field according to standard methods described in the National Field Manual by the U.S. Geological Survey (1997-present). Constituents included dissolved ammonia, dissolved nitrite plus nitrate, dissolved orthophosphate, total phosphorus, Escherichia coli, fecal coliform bacteria, and suspended sediment (table 4). Nutrient samples were analyzed at the USGS National Water Quality Laboratory (NWQL, Lakewood, Colo.) as described by Fishman (1993). Suspendedsediment samples were collected as described by Edwards and Glysson (1988) and analyzed at the USGS Iowa Water Science Center Sediment Laboratory using methods described by Guy (1969). Escherichia coli and fecal coliform bacteria samples were processed, incubated, and counted in the Colorado Water Science Center Pueblo office laboratory as described by the U.S. Geological Survey (1997-present). Mau and others (2007) provide detailed information concerning water-chemistry collection methods, interpretation of water-chemistry data, as well as information concerning quality assurance/quality control of water-chemistry data collected during the study period.

Fish. Fish community data were collected at main stem sites along Fountain Creek in mid-September during baseflow conditions (table 1). All sites were wadable at the time of sampling. Each reach was electrofished in an upstream direction with a single pass (Pusey and others, 1998) using Smith-Root pulsed DC backpack electroshockers (model 12B POW and model 15D POW). A concerted effort was made to sample all available habitats along each reach. The length of 
Table 2. Basin and stream-reach habitat variables used to characterize selected sites in the Fountain Creek basin, Colorado, 2003-2005.

[mi² , square miles; mi, miles; \%, percent; ft, feet; NAVD 88, North American Vertical Datum of 1988; m, meters; ft/s, feet per second; mm, millimeters; RBP, rapid bioassessment protocols; $>$, greater than]

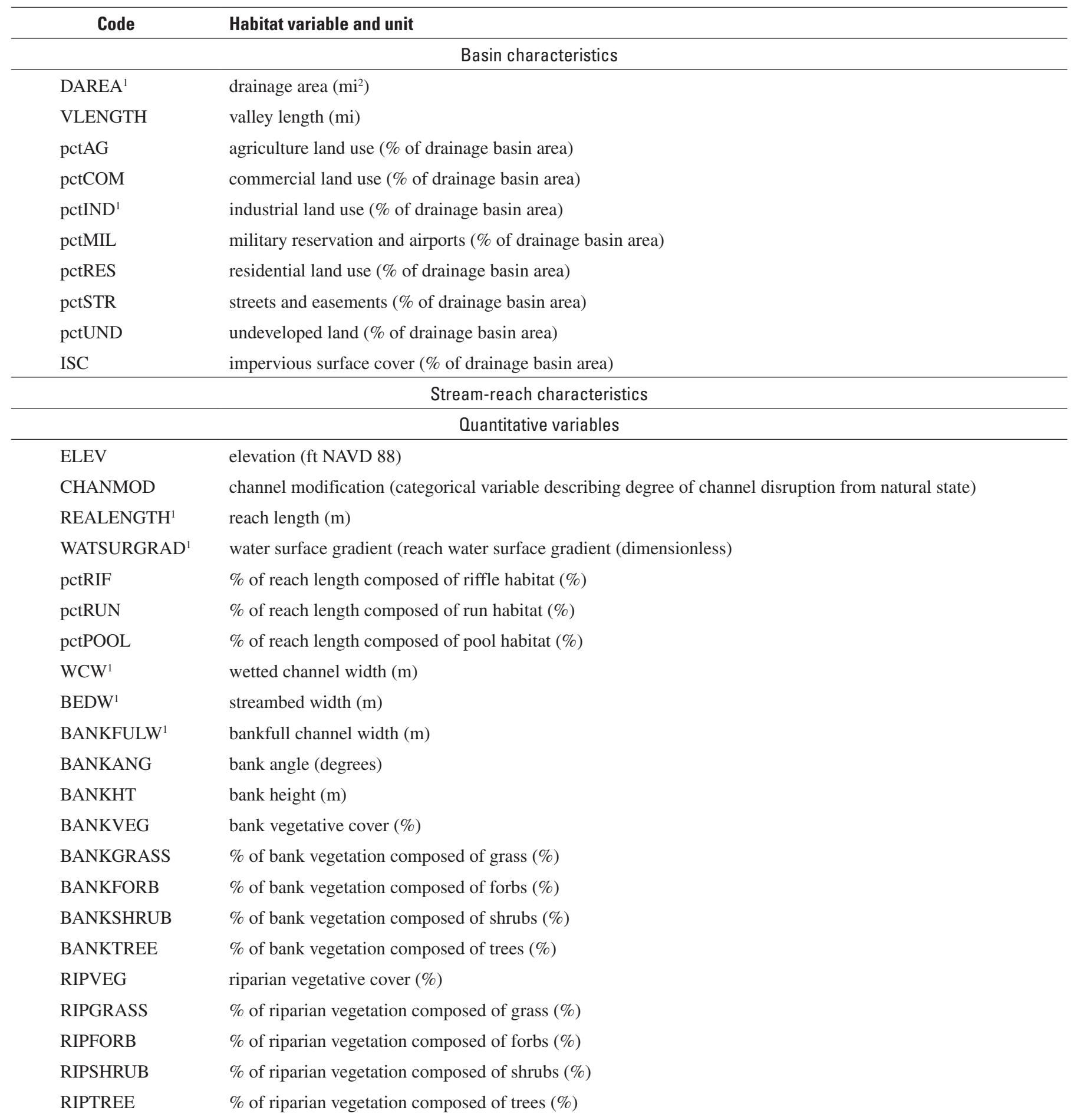


Table 2. Basin and stream-reach habitat variables used to characterize selected sites in the Fountain Creek basin, Colorado, 2003-2005.-Continued

[mi², square miles; mi, miles; \%, percent; ft, feet; NAVD 88, North American Vertical Datum of 1988; m, meters; ft/s, feet per second; mm, millimeters; RBP, rapid bioassessment protocols; $>$, greater than

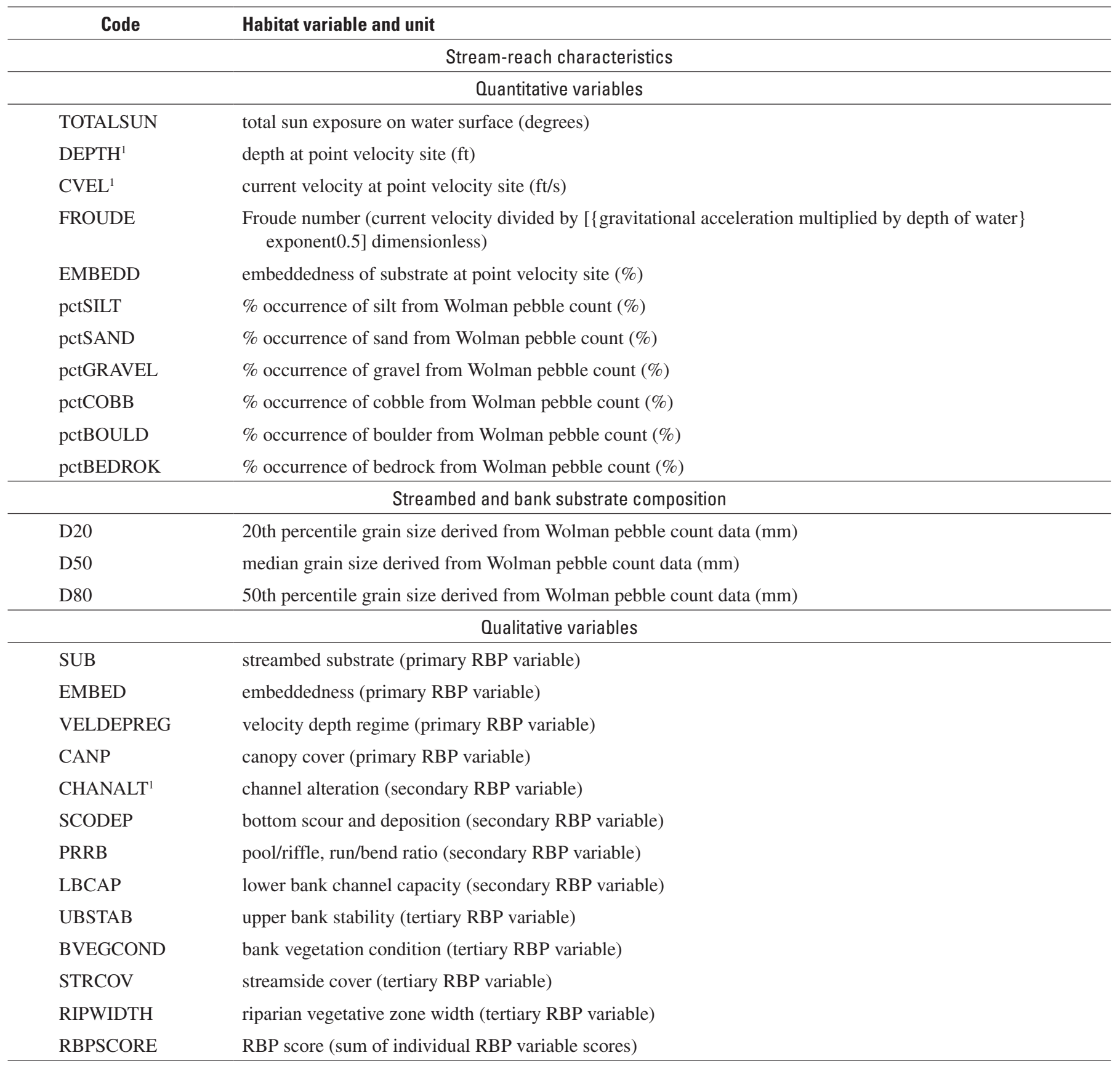

${ }^{1}$ Spearman's rho between variable and elevation $>0.6$. 
Table 3. Coefficients used to convert land use to impervious surface coverage in the Fountain Creek basin, Colorado, 2003-2005.

\begin{tabular}{|c|c|c|}
\hline Land use category & Land use subcategory & $\begin{array}{l}\text { Coefficient of } \\
\text { imperviousness, } \\
\text { in percent }^{1}\end{array}$ \\
\hline Undeveloped land & & 2 \\
\hline Agriculture & & 4 \\
\hline Military reservations and airports & & 13 \\
\hline \multirow[t]{6}{*}{ Residential } & $1 / 2$ - acre or larger lot & 12 \\
\hline & $1 / 4$ - to $1 / 2$ - acre lot & 21 \\
\hline & $1 / 8$ - to $1 / 4$ - acre lot & 28 \\
\hline & high density detatched housing & 39 \\
\hline & condominiums and apartment buildings & 65 \\
\hline & undefined housing & 33 \\
\hline \multirow[t]{6}{*}{ Commercial } & low impact office & 20 \\
\hline & schools & 35 \\
\hline & unimproved parking lots & 60 \\
\hline & neighborhood commercial & 70 \\
\hline & high density commercial & 85 \\
\hline & parking structures & 98 \\
\hline \multirow[t]{3}{*}{ Industrial } & office and light industrial park & 35 \\
\hline & warehouse & 70 \\
\hline & mining & 85 \\
\hline \multirow[t]{3}{*}{ Streets and easements } & utility easement and undefined streets & 60 \\
\hline & collector streets & 85 \\
\hline & arterial streets & 98 \\
\hline
\end{tabular}

\footnotetext{
${ }^{1}$ Arnold and Gibbons (1996) and Pikes Peak Area Council of Governments (2005).
}

the reach sampled ranged from 42 to $300 \mathrm{~m}$ (138 to $984 \mathrm{ft}$ ). After capture, fish were maintained in aerated live wells. All fish were identified, enumerated, and measured (total length) in the field, tallied in the nearest $2-\mathrm{cm}(0.79$ inch) length class, observed for anomalies, and released. Species-level field identification was problematic for only small young-of-the-year fish $(<20 \mathrm{~mm})$, but these accounted for less than 0.1 percent of the total catch. Voucher specimens of anomalous fish were retained by the CDOW. The CDOW also submitted fish from different trophic guilds at selected sites to the Colorado Department of Public Health and Environment (CDPHE) for tissue analysis.

Invertebrates. Invertebrates were sampled each year during base-flow conditions in October several weeks after fish sampling. A Hess sampler $\left(0.086 \mathrm{~m}^{2}\right.$ or $\left.0.923 \mathrm{ft}^{2}\right)$ equipped with $500-\mu \mathrm{m}$ mesh was used to collect three replicate samples from the expected richest targeted habitat (RTH). The intent of this study was to use a sampling approach to sample consistent RTH (riffles) at all sites. However, when riffles were absent in a stream reach, runs with the coarsest substrate were sampled. A random numbers table was used to determine the number of steps from the downstream boundary for the three sample locations within the length of the selected RTH (riffle or run). Randomly selected points were rejected if the point was outside the boundary of the RTH, and were replaced with alternative randomly generated points. If a sample point could not be sampled due to the substrate exceeding the limit of the sampler, the point was moved laterally or upstream one step. Attempts were made to sample the same habitat type at each site every year, but in Fountain Creek runs and riffles are not spatially stable due to streambed alteration caused by naturally shifting sand, stormflows, and episodic utility construction within the channel. Samples were collected in a downstream to upstream direction. The Hess sampler was pushed firmly into the streambed and the substrate was mixed to dislodge invertebrates. When present, cobbles were scrubbed inside the sampler to further remove clinging invertebrates and inspected for remaining invertebrates. The remaining substrate within the sampler was stirred by hand or a sturdy metal utensil to a depth of approximately $0.10 \mathrm{~m}$ to dislodge invertebrates from smaller substrate and those dwelling within the substrate. The sampler was rinsed with stream water between sample collections to minimize cross-contamination between samples 
Table 4. Water-chemistry variables used to characterize selected sites in the Fountain Creek basin, Colorado, 2003-2005.

$[/$, per; $\mathrm{mg} / \mathrm{L}$, milligrams per liter; $\mu \mathrm{S} / \mathrm{cm}$, microsiemens per centimeter at $25^{\circ} \mathrm{C}$; ${ }^{\circ} \mathrm{C}$, degrees Celsius; $\mathrm{col} / 100 \mathrm{~mL}$, colonies per 100 milliliters; $\mathrm{mL}$, milliliters; >, greater than]

\begin{tabular}{ll}
\hline \multicolumn{1}{c}{ Code } & \multicolumn{1}{c}{ Water-quality variable and unit } \\
\hline DO & dissolved oxygen $(\mathrm{mg} / \mathrm{L})$ \\
$\mathrm{PH}$ & $\mathrm{pH}$ \\
$\mathrm{SC}^{1}$ & specific conductance $(\mu \mathrm{S} / \mathrm{cm})$ \\
$\mathrm{WT}$ & water temperature $\left({ }^{\circ} \mathrm{C}\right)$ \\
$\mathrm{DNH} 4$ & dissolved ammonia $(\mathrm{mg} / \mathrm{L}$ as $\mathrm{N})$ \\
$\mathrm{DNO} 23$ & dissolved nitrite plus nitrate $(\mathrm{mg} / \mathrm{L}$ as $\mathrm{N})$ \\
$\mathrm{DOP}$ & dissolved orthophosphate $(\mathrm{mg} / \mathrm{L}$ as $\mathrm{P})$ \\
$\mathrm{TP}$ & total phosphorus $(\mathrm{mg} / \mathrm{L}$ as $\mathrm{P})$ \\
EC & Escherichia coli $($ col/100 $\mathrm{mL})$ \\
FC & fecal coliform bacteria $(\mathrm{col} / 100 \mathrm{~mL})$ \\
SEDCONC & suspended-sediment concentration $(\mathrm{mg} / \mathrm{L})$ \\
\hline
\end{tabular}

${ }^{1}$ Spearman's rho between variable and elevation $>0.6$.

and sites. In addition to RTH samples, a dip net equipped with $500-\mu \mathrm{m}$ mesh was used to collect a qualitative multihabitat $(\mathrm{QMH})$ sample after the RTH samples had been collected. Organisms in QMH samples were collected from all available habitat types within the stream reach. QMH samples contained a considerable amount of debris that was reduced in the field by elutriating and sieving (500- $\mu \mathrm{m}$ mesh metal sieve) until sample volumes were approximately $500 \mathrm{~mL}$ (about 1 pint).

Invertebrate samples were preserved in the field with either 95-percent ethanol or 10-percent buffered formalin, and stored until they could be delivered to the contract laboratory (Chadwick and Associates in Littleton, Colo., or Aquatic Associates in Ft. Collins, Colo.) for identification. Sample processing, taxa identification, and enumeration conformed to the protocols developed by Moulton and others (2000). A voucher collection was prepared and updated annually and verified by the USGS NWQL. The NWQL also evaluated sorting efficiency for 5 percent of the RTH samples, which was found acceptable.

\section{Data Analysis}

Hydrologic indices that describe stormwater flows associated with urbanization (ISC) were evaluated to determine their association with habitat and water chemistry. These data were then combined to determine the subset of environmental variables that best described patterns in fish and invertebrate community structure.

Correlation analysis (Spearman's rho) and examination of scatter plots with loess smoothing was used to evaluate the strength and form of the associations within variable types and among variables. In addition, a p-value $<0.05$ (95-percent confidence that the statistical test is valid) was used to reject the null hypothesis for all tests. Spearman's rho, which is based on the ranks of the values, was used because this measure can account for nonlinear relations. Correlation analysis also was used to identify highly correlated variables (Spearman's rho > 0.9) within each variable group (hydrologic, habitat, water chemistry), so that the list of variables could be reduced to relate to biological communities.

Biological communities are highly correlated with elevation in Colorado streams (Ward, 1986; Rahel and Hubert, 1991). To alleviate the influence of elevation in the analysis, environmental variables were removed if they were highly correlated with elevation (Spearman's rho > 0.6). Minimizing the effects of elevation in the analysis should help clarify the influence of urban-related environmental variables on the structure of biological communities in the Fountain Creek basin.

The exploratory multivariate BIO-ENV procedure was used as the final analysis to identify the best match between community structure and a subset of environmental variables associated with those samples. Finally, a conceptual model describing the relations between ISC, stormwater hydrology, habitat, water chemistry, and fish and invertebrate community structure was constructed to guide future aquatic monitoring efforts. Correlation analyses were conducted using S-Plus 2000 (Mathsoft, Inc., 2000), and the BIO-ENV routine was computed using PRIMER version 6.1 software, Plymouth Routines in Multivariate Ecological Research (Clarke and Warwick, 2001).

\section{Stream Hydrology}

Mean daily and instantaneous peak streamflow from 13 on-site USGS continuous streamgages were imported to the Hydrologic Index Tool (HIT) software (Henriksen and others, 2006) to calculate hydrologic indices (HIs) that describe various aspects of streamflow. The HIT calculates $171 \mathrm{HIs}$ that are distributed among the five major components of the flow regime: magnitude, frequency, duration, timing, and rate of change (Olden and Poff, 2003 and citations within). Because streamflow data were evaluated on a yearly basis, which effectively removed indices related to timing and periodicity, only 132 of the 171 HIs could be calculated. Twenty-three of the 132 HIs were selected for further analysis because they were expected to, or have been demonstrated in the literature to be, influenced by urbanization (Walsh and others, 2005) (table 5). Correlation analysis (Spearman's rho) was used to reduce further the number of variables by removing redundant variables (rho $>0.9$ ), and those related to elevation (rho $>0.6$ ), and to relate the remaining variables to ISC (rho $>0.6$ ). 
Table 5. Hydrologic indices calculated to characterize the flow regimes from selected sites in the Fountain Creek basin, Colorado, 2003-2005.

[ft $\mathrm{ft}^{3} / \mathrm{s}$, cubic feet per second; CV, coefficient of variation; /, per; $\mathrm{mi}^{2}$, square miles; <, less than or equal to; $>$, greater than or equal to]

\begin{tabular}{|c|c|c|c|}
\hline Flow regime & Code & Hydrologic variable description & Unit \\
\hline Magnitude & MA2 $^{1}$ & Annual daily mean flow & $\mathrm{ft}^{3} / \mathrm{s}$ \\
\hline Magnitude & MA3 & Variability of annual daily mean flow (CV of annual daily mean flow) & percent \\
\hline Magnitude & ML7 & Minimum July daily mean flow & $\mathrm{ft}^{3} / \mathrm{s}$ \\
\hline Magnitude & ML14 & Minimum annual daily mean flow & $\mathrm{ft}^{3} / \mathrm{s}$ \\
\hline Magnitude & $\mathrm{MH} 7^{1}$ & Maximum July daily mean flow & $\mathrm{ft}^{3} / \mathrm{s}$ \\
\hline Magnitude & MH14 & $\begin{array}{l}\text { Annual maximum flow computed from monthly maximum flows, } \\
\text { divided by the median annual flow }\end{array}$ & dimensionless \\
\hline Magnitude & MH20 & Drainage area normalized annual maximum daily mean flow & $\mathrm{ft}^{3} / \mathrm{s} / \mathrm{mi}^{2}$ \\
\hline Frequency & FH5 & Flood frequency (number of events $>$ median) & number of events /year \\
\hline Duration & DL1 & Annual daily minimum flow & $\mathrm{ft}^{3} / \mathrm{s}$ \\
\hline Duration & $\mathrm{DL}^{1}$ & Annual 7-day mimimum average flow & $\mathrm{ft}^{3} / \mathrm{s}$ \\
\hline Duration & $\mathrm{DH} 1^{1}$ & Annual maximum daily flow & $\mathrm{ft}^{3} / \mathrm{s}$ \\
\hline Duration & $\mathrm{DH} 2^{1}$ & Annual maximum 3-day average flow & $\mathrm{ft}^{3} / \mathrm{s}$ \\
\hline Duration & DH15 & High flow pulse duration (duration for flow events $>75$ th percentile) & days/year \\
\hline Rate of change & RA $^{1}$ & Rise rate (positive change in flow for consecutive days) & $\mathrm{ft}^{3} / \mathrm{s} /$ day \\
\hline Rate of change & RA2 & Variability of rise rate ( $\mathrm{CV}$ of rise rate) & percent \\
\hline
\end{tabular}

${ }^{1}$ Spearman's rho between variable and elevation $>0.6$.

\section{Habitat}

Habitat data were summarized as either relative percentages of reach length, as minimum, maximum, mean or median values, or as RBP scores (table 2). Correlation analysis (Spearman's rho) was used to eliminate redundant variables (rho $>0.9$ ), to remove those variables related to elevation (rho $>0.6$ ), and to relate the remaining variables to ISC (rho >0.6).

\section{Water Chemistry}

Water chemistry can differ substantially between stormflow and nonstormflow conditions as well as spatially in the Fountain Creek basin (Edelmann and others, 2002; Mau and others, 2007). Both of these reports indicated that stormflow chemistry is highly variable. The scope of this study was not broad enough to fully characterize chemical conditions during stormflow conditions at all sites. As a result there were not enough stormflow chemistry samples collected to relate stormflow chemistry to biology in a meaningful way. Therefore, water chemistry during nonstormflow conditions was used to relate water chemistry to urbanization and biological communities in the Fountain Creek basin during 2003-2005. To meet these criteria, the National Water Information System (NWIS) database was queried to extract nonstormflow water-chemistry samples that corresponded to sites during 2003-2005. The hydrograph was further analyzed to ensure that the samples had not been misidentified, and were indeed collected during nonstormflow conditions. Data were summarized as maximums, minimums, means, medians, and coefficients of variation (table 3). Correlation analysis (Spearman's rho) was used to eliminate redundant variables (rho $>0.9$ ), to remove 
those variables related to elevation (rho $>0.6$ ), and to relate the remaining variables to ISC (rho > 0.6) as was done for the HIs and habitat.

\section{Resolution of Taxonomic Ambiguities}

Ambiguous taxa occur in biological data sets when closely related specimens are identified at different levels of taxonomic resolution. Distinguishing characteristics used to identify a taxon are generally described from mature specimens that may be absent in immature or damaged specimens. As a result, a sample may contain a group of individuals from the same genus (parent taxon), but not all can be identified to the species level (child taxon). Including ambiguous taxa in a data set can artificially increase richness or change similarities among samples collected from a series of sites. For the fish data, young-of-the-year could not be identified in the field so they were removed from the data set, thereby resolving all ambiguities because all other individuals were identified to species. Invertebrate ambiguities were resolved by comparing the abundances of ambiguous parent and children taxa using the Invertebrate Data Analysis System (IDAS) software (Cuffney, 2003). If the abundance of the parent was greater than the sum of the children's abundances, the children were deleted and their abundances were added to the parent's abundance. Otherwise, the children were retained and the parent was deleted.

\section{Relating Urban Hydrology, Habitat, and Water Chemistry to Fish and Invertebrate Community Structure}

After data reduction as described above, the BIO-ENV procedure in the PRIMER version 6.1 software package (Clarke and Ainsworth, 1993) was used to link environmental variables to fish and invertebrate community structure. BIOENV is an exploratory nonparametric multivariate procedure that identifies the best match between community structure and a subset of environmental variables associated with those samples. The rationale is that if the environmental variables structuring a community were known, then samples having similar values for these environmental variables would have similar biological communities, and separate ordinations of the environmental variables and species composition would be similar (Clarke and Warwick, 2001). The match (Spearman's rho) between the ordinations deteriorates if key environmental variables driving community structure are omitted or if environmental variables irrelevant to driving community structure are included. BIO-ENV calculates a Spearman's rho value for ordinations of each possible combination of the environmental variables with an ordination of species composition. The subset of environmental variables with the best fitting match (highest rho value) to the species composition ordination is determined to be the best subset that describes community structure within the bounds of the data set.

The underlying ordination method used in the BIO-ENV procedure is nonmetric multidimensional scaling (MDS). The main advantages of MDS over other ordination techniques is that MDS does not make any assumptions about the form of the data or the interrelations of the samples, and it has greater ability than other ordination methods to represent complex relations in low dimensional space (Clarke and Warwick, 2001). Before data were analyzed, environmental variables were $\log _{10}$ transformed and normalized by subtracting the mean from the observation and by dividing by the standard deviation. A fourth-root transformation was applied to RTH invertebrates and fish to down weight common taxa (Clarke and Warwick, 2001). The presence-absence data associated with invertebrate QMH samples were not transformed. After transformation, separate similarity matrices were calculated using Bray-Curtis similarity for biological data and Euclidean distance for the environmental data (Clarke and Warwick, 2001).

Results of the BIO-ENV routine and the data reduction process described earlier were used to develop a conceptual model of the relations between urban related hydrology, habitat, and nonstormflow chemistry, with fish and invertebrate community structure in the Fountain Creek basin, 2003-2005. The conceptual model is intended in part to guide future work relating environmental variables to biological communities in the Fountain Creek basin.

\section{Urban-Related Environmental Variables}

After the removal of redundant variables and variable reduction as described previously in the Data Analysis section, the environmental data set of 93 variables was reduced to 8 that were related to ISC but not related to elevation-four HIs, three habitat, and one nonstormflow water chemistry (table 6). The data reduction process restricted the analysis to those streamflow, habitat, and nonstormflow chemistry variables that were related to urbanization. Designing a study to separate the effects of changes in biological communities that occur naturally along a longitudinal elevation gradient from urbanization along the Front Range of Colorado is challenging. By also removing those variables that were related to elevation from the final list, it was assumed that the influence of known longitudinal elevation gradients inherent with this dataset could be partially removed from the analysis. Therefore, the results of the BIO-ENV analysis should be an indication of the strength of the influence of the remaining urban-related environmental variables in the dataset on biological communities. 
Table 6. Correlation matrix showing Spearman's rho values relating impervious surface cover and eight environmental variables used in the exploratory multivariate analysis (BIO-ENV procedure). All correlations were significant at $\mathrm{P}<0.05$.

[ISC, impervious surface cover; MH20, drainage area normalized annual maximum daily mean flow; FH1, high flood pulse count 1; FH5, flood frequency; RA8, number of reversals; pctPOOL, percent of reach length comprised of pool; LBCAP, lower bank channel capacity; MAXBANKHT, maximum bank height; DNO23, dissolved nitrite plus nitrate; <, less than]

\begin{tabular}{|c|c|c|c|c|c|c|c|c|c|}
\hline $\begin{array}{c}\text { Environmental } \\
\text { variable type }\end{array}$ & Variable code $^{1}$ & ISC & MH2O & FH1 & FH5 & RA8 & pctP00L & LBCAP & MAXBANKHT \\
\hline Streamflow & MH20 & 0.81 & & & & & & & \\
\hline Streamflow & FH1 & 0.76 & 0.56 & & & & & & \\
\hline Streamflow & FH5 & 0.63 & 0.48 & 0.66 & & & & & \\
\hline Streamflow & RA8 & 0.66 & 0.61 & 0.62 & 0.69 & & & & \\
\hline Habitat & pctPOOL & -0.67 & -0.66 & -0.70 & -0.55 & -0.54 & & & \\
\hline Habitat & LBCAP & -0.63 & -0.67 & -0.63 & -0.47 & -0.44 & 0.70 & & \\
\hline Habitat & MAXBANKHT & 0.69 & 0.59 & 0.66 & 0.39 & 0.34 & -0.42 & -0.47 & \\
\hline Chemistry & DNO23 & 0.70 & 0.66 & 0.55 & 0.46 & 0.55 & -0.58 & -0.70 & 0.56 \\
\hline
\end{tabular}

${ }^{1}$ See tables 2,4 and 5 .

\section{Stream Hydrology}

In this study, a pattern consistent with previously observed responses of stream hydrology to urbanization (Poff and others, 1997; Walsh and others, 2005) was evident (table 6). All of the HIs are considered measurements of stormflow hydrology, such as high flow magnitude (MH20), high flow frequency (FH1 and FH5), and stream flashiness (RA8, number of reversals). This finding suggested that the influence of urbanization was associated with stormflow hydrology in the Fountain Creek basin during the study period. Two of the stormflow variables (MH20 and FH1) had the strongest relation (rho values $=0.81$ and 0.76 ) with urbanization, measured as ISC (table 6).

Unlike previous studies in the arid West (McMahon and others, 2003; Sprague and others, 2006) that had limited success in associating the effects of urbanization with streamflow characterization, this study provided evidence linking urbanization with stream hydrology - specifically stormflow hydrology in the Fountain Creek basin. The differential success of these studies might be attributable to the hydrologic data that were collected, computed, and analyzed or the differences in study design. The McMahon and others (2003) and Sprague and others (2006) studies were gradient designs that sampled many sites along a gradient of urbanization over a short time period. In the gradient design, there may not have been enough storms that affected each site along the gradient of urbanization, coupled with the intense water management that occurs in arid areas, to signal a response in hydrology. Urbanization, climate, and intense water regulation, including transbasin diversions, agricultural and domestic water use, reservoir storage, and WWTF discharge were common in part to all of these studies.

This study differed from those of McMahon and others (2003) and Sprague and others (2006) by using continuous stream discharge rather than stage-related data to characterize stream hydrology over 3 years. Natural stream channels experience episodes of scour and deposition that are often associated with the ascending and falling limbs of a stream rise (Rantz and others, 1982). Because of this, the relation between stream discharge and stage-related data must be defined empirically with stream discharge measurements on a periodic or stream-rise basis. Thus the use of stage-related data as a surrogate for continuous stream discharge might not be appropriate or accurate in the West or on streams with unstable stage-discharge relations, which are fairly common along the Front Range of Colorado. Additionally, monitoring stream discharge and simultaneous changes in urbanization over multiple years may have made the relation between hydrology and urbanization more apparent in this study.

\section{Habitat}

Three habitat variables also were strongly correlated with ISC in the study area, and other urban- related factors-stormflow and water chemistry (table 6). Percent pool, bank height, and lower bank capacity can be categorized as measurements of channel morphology. The geomorphic channel features, percent pool and bank height, were measured directly. Lower bank capacity is an RBP habitat characteristic that received 
a ranked score, but the ranking required the measurement of the width-to-depth ratio of the channel in the stream reach. These relations were consistent with previous studies, which determined that streamflow has a direct influence on channel morphology features, such as bank height, bank angle, channel width, and streambed substrate (Konrad and Booth, 2005). Previous National Water-Quality Assessment Program (NAWQA) gradient studies have not found such strong correlations between urbanization and environmental variables (Short and others, 2005).

Results from this study indicated that stormflow was strongly related to urbanization and habitat. The erosive properties of higher and more attenuated peak flows have the ability to alter stream geomorphology by destroying riffles and pools, destabilizing banks, widening channels, and filling interstitial spaces between gravels and cobbles (Burton and Pitt, 2002; Pizzuto and others, 2000). In this study direct measurements were made of stream habitat features except bank stability. However, bank height and angle were measured as surrogates for bank stability. The destruction of substrate heterogeneity by sediment deposition at sites with unstable banks directly eliminates habitat required by benthic communities (Wood and Armitage, 1997). Increased sediment transport during high flows also has the potential to bury or scour entire localized populations of invertebrates (Matthaei and others, 1999; Waters, 1995). Reproductive success of lithophilic fish spawners, such as the cyprinids, central stoneroller, and longnose dace and the percid Arkansas darter also might be reduced because of the alteration of suitable spawning habitats, smothering of eggs, or decreased emergence caused by the entrapment of larval fish. Also, sediment deposition could decrease growth and recruitment of fish populations by altering the availability of food sources.

\section{Water Chemistry}

Dissolved nitrite plus nitrate (milligrams per liter), a nutrient, was the only water chemistry constituent related to ISC and other urban-related environmental variables in this study (table 6). This observation was consistent with previous studies, but unlike those studies, other consistent responses of water chemistry in response to urbanization were not detected in the current study. Those responses include increases in water temperature, specific conductance, and bacteria (Walsh and others, 2005; Coles and others, 2004; Tate and Heiny, 1995). However, additional water chemistry data including metals, trace elements, volatile organic compounds, and pesticides were not collected at all sites during this study, but have been demonstrated to be associated with urbanization as well as having biological effects on aquatic communities (Sprague and others, 2006; Kennen and Ayers, 2002). Sprague and others (2006) completed their work nearby in the South Platte River basin and used semipermeable membrane devices (SPMDs) to sample organic compounds. Their results indicated strong relation between urbanization and polycyclic aromatic hydrocarbons (PAHs).

\section{Relating Urban-Related Environmental Variables with Patterns in Biological Community Structure}

\section{Fish Communities}

Results of BIO-ENV indicated that urban-related environmental variables poorly explained patterns in fish community structure in the Fountain Creek basin (table 7). Of the 255 possible combinations of the 8 environmental variables evaluated for explaining fish community structure, the best subset only correlated with fish community structure at rho $=0.25$ (subset 18, table 7). This two-variable subset included the variables nitrite plus nitrate concentration and maximum bank height.

Several studies have shown changes in fish community structure associated with urbanization (Long and Schorr, 2005; Roy and others, 2005; Albanese and Matlack, 1999; Wang and others, 1997). Typically, diversity declines and the abundance of tolerant species increases with increasing urbanization (Paul and Meyer, 2001). Many of these previous studies were conducted in areas of high fish diversity ( $>30$ species per site) with a wide variety of specialist or endemic species. In this study, and in an urban gradient study in the South Platte River basin (Sprague and others, 2006), no strong associations between urban-related hydrology or other meaningful measures of urbanization and fish community structure were found. This lack of strong association between urbanization and fish community structure in these two regional studies might be the result of current fish distribution patterns in many small transition zone streams of Colorado, where sites are dominated by a relatively small number of generalist species ( $<6$ species per site).

Even under natural conditions, fish assemblages of streams in the Great Plains typically are comprised of more tolerant species than assemblages in less extreme habitats (Matthews, 1986). This, combined with human-induced streamflow modifications, habitat alterations, and changes in water quality that have occurred for nearly 150 years in transition zone streams (Fausch and Bestgen, 1997), likely truncated present day fish faunas to those that can tolerate a wide variety of extreme environmental conditions. The present-day tolerant fish assemblage probably minimized the urban-related effects on fish community structure in this and in the Sprague and others (2006) study. Similar results have been observed in Coastal Plain streams of Maryland, where early modifications to stream systems truncated local fish faunas, possibly masking fish-community response to contemporary urbanization (Morgan and Cushman, 2005). Others have suggested that fish-community structure is not a good indicator of stream health in nearby plains streams of Colorado for similar reasons (Bramblett and Fausch, 1991; Schrader, 1989). 
Table 7. Correlation coefficients associated with the best subsets of urban-related environmental variables describing biological community structure from the exploratory multivariate analysis (BIO-ENV procedure).

[Each subset presented represents the highest correlation of 1 through 8 variable combinations for each assemblage type. The strongest and most parsimonious subset is bolded. QMH, qualitative multihabitat; Nitrite + Nitrate Concentration, dissolved nitrite plus nitrate concentration; Max, maximum; Pct, percent; RTH, richest targeted habitat]

\begin{tabular}{|c|c|c|c|}
\hline $\begin{array}{l}\text { Subset } \\
\text { number }\end{array}$ & $\begin{array}{l}\text { Number of } \\
\text { variables }\end{array}$ & $\begin{array}{c}\text { Spear- } \\
\text { man's rho }\end{array}$ & Variables included in model \\
\hline \multicolumn{4}{|r|}{ Invertebrate $\mathrm{QMH}$} \\
\hline 1 & 1 & 0.56 & Lower Bank Capacity \\
\hline 2 & 2 & 0.67 & Nitrite + Nitrate Concentration, Lower Bank Capacity \\
\hline 3 & 3 & 0.71 & Nitrite + Nitrate Concentration, Flood Pulse Count, Lower Bank Capacity \\
\hline 4 & 4 & 0.71 & Nitrite + Nitrate Concentration, Flood Pulse Count, Flood Frequency, Lower Bank Capacity \\
\hline 5 & 5 & 0.70 & Nitrite + Nitrate Concentration, Flood Pulse Count, Flood Frequency, Mean Annual Normalized Max Flow, Lower Bank Capacity \\
\hline 6 & 6 & 0.71 & Nitrite + Nitrate Concentration, Flood Pulse Count, Flood Frequency, Number of Reversals, Mean Annual Normalized Max Flow, Lower Bank Capacity \\
\hline 7 & 7 & 0.70 & Nitrite + Nitrate Concentration, Flood Pulse Count, Flood Frequency, Number of Reversals, Mean Annual Normalized Max Flow, Pct Pool, Lower Bank Capacity \\
\hline 8 & 8 & 0.67 & $\begin{array}{l}\text { Nitrite + Nitrate Concentration, Flood Pulse Count, Flood Frequency, Number of Reversals, Mean Annual Normalized Max Flow, Pct Pool, Lower Bank Capacity, Max } \\
\text { Bank Height }\end{array}$ \\
\hline \multicolumn{4}{|r|}{ Invertebrate RTH } \\
\hline 9 & 1 & 0.28 & Mean Annual Normalized Max Flow \\
\hline 10 & 2 & 0.33 & Mean Annual Normalized Max Flow, Lower Bank Capacity \\
\hline 11 & 3 & 0.35 & Flood Pulse Count, Mean Annual Normalized Max Flow, Lower Bank Capacity \\
\hline 12 & 4 & 0.34 & Nitrite + Nitrate Concentration, Flood Pulse Count, Mean Annual Normalized Max Flow, Lower Bank Capacity \\
\hline 13 & 5 & 0.33 & Nitrite + Nitrate Concentration, Flood Pulse Count, Number of Reversals, Mean Annual Normalized Max Flow, Lower Bank Capacity \\
\hline 14 & 6 & 0.32 & Nitrite + Nitrate Concentration, Flood Pulse Count, Number of Reversals, Mean Annual Normalized Max Flow, Lower Bank Capacity, Max Bank Height, \\
\hline 15 & 7 & 0.30 & Nitrite + Nitrate Concentration, Flood Pulse Count, Number of Reversals, Mean Annual Normalized Max Flow, Pct Pool, Lower Bank Capacity, Max Bank Height \\
\hline 16 & 8 & 0.29 & $\begin{array}{l}\text { Nitrite + Nitrate Concentration, Flood Pulse Count, Flood Frequency, Number of Reversals, Mean Annual Normalized Max Flow, Pct Pool, Lower Bank Capacity, Max } \\
\text { Bank Height }\end{array}$ \\
\hline \multicolumn{4}{|r|}{ Fish } \\
\hline 17 & 1 & 0.16 & Max Bank Height \\
\hline 18 & 2 & 0.25 & Nitrite + Nitrate Concentration, Max Bank Height \\
\hline 19 & 3 & 0.24 & Nitrite + Nitrate Concentration, Lower Bank Capacity, Max Bank Height \\
\hline 20 & 4 & 0.23 & Nitrite + Nitrate Concentration, Flood Pulse Count, Lower Bank Capacity, Max Bank Height \\
\hline 21 & 5 & 0.20 & Nitrite + Nitrate Concentration, Flood Pulse Count, Mean Annual Normalized Max Flow, Lower Bank Capacity, Max Bank Height \\
\hline 22 & 6 & 0.17 & Nitrite + Nitrate Concentration, Flood Pulse Count, Flood Frequency, Mean Annual Normalized Max Flow, Lower Bank Capacity, Max Bank Height \\
\hline 23 & 7 & 0.13 & $\begin{array}{l}\text { Nitrite + Nitrate Concentration, Flood Pulse Count, Flood Frequency, Number of Reversals, Mean Annual Normalized Max Flow, Lower Bank Capacity, Max Bank } \\
\text { Height }\end{array}$ \\
\hline 24 & 8 & 0.09 & $\begin{array}{l}\text { Nitrite + Nitrate Concentration, Flood Pulse Count, Flood Frequency, Number of Reversals, Mean Annual Normalized Max Flow, Pct Pool, Lower Bank Capacity, Max } \\
\text { Bank Height }\end{array}$ \\
\hline
\end{tabular}




\section{Invertebrate Communities}

Previous urban-impact studies have found strong invertebrate community response to urbanization (Coles and others, 2004; Roy and others, 2003; Kennen, 1999; Jones and Clark 1987). Typically, pollution tolerant taxa replace pollution sensitive taxa resulting in changes in diversity and invertebrate abundance as urbanization increases (Paul and Meyer, 2001). Several local studies have found mixed results regarding the direct influence of urbanization on invertebrate community structure. In nearby urban-related studies in the South Platte River basin, Sprague and others (2006) did not find any strong relations between urbanization and invertebrate community structure; whereas others were able to show at least partial effects (Voelz and others, 2005; Tate and Heiny, 1995).

In this study, several combinations of urban related variables were strongly related to invertebrate community structure (table 7). The strongest and most parsimonious relation of any BIO-ENV subset $($ rho $=0.71)$ was between $\mathrm{QMH}$ data and three environmental variables that represented hydrology (FH1-flood pulse count), habitat (lower bank capacity), and water chemistry (nitrite plus nitrate concentration), (subset 3 , table 7). In addition, there were several other competing subsets that described similar correspondence between other combinations of environmental variables and patterns in $\mathrm{QMH}$ community structure (table 7). The three variables in subset 3, table 7 (FH1-flood pulse count, lower bank capacity, and nitrite plus nitrate concentration) were consistently found in all competing QMH subsets indicating that these three variables are likely contributing most to matching patterns in environmental and QMH ordinations. Interestingly, the addition of other environmental variables (FH5-flood frequency, MH20drainage area normalized annual maximum daily mean flow and percent pool) into subsequent subsets did not deteriorate the relation between QMH community structure and urbanrelated environmental variables (subsets 4-7, table 7). This may indicate that even with a relatively intense variable reduction process described above, there was still some redundancy among environmental variables as they are related to QMH community structure.

The BIO-ENV subset with the strongest correlation to RTH community structure consisted of two hydrologic variables (FH1-flood pulse count, MH20- drainage area normalized annual maximum daily mean flow) and one habitat variable (lower bank capacity) (subset 11, table 7). Although this was the strongest BIO-ENV subset for the RTH data, the relation between patterns in RTH community structure and environmental variables was relatively weak $(\mathrm{rho}=0.35)$. As with the QMH data, there were other competing subsets that described RTH community structure almost as well as subset 11 (subsets 10,12,13, table 7), again suggesting at least some redundancy across environmental variables. Interestingly, flood pulse count and lower bank capacity were included in RTH and QMH best subsets (table 7), which might be a result of the overlap in taxa between the two sample types (RTH with 145 taxa, QMH with 205 taxa) and how they related to the environmental variables in the subset.

Varying results between this and previous studies are likely caused by differences in study design. Studies that collected samples from several sites across a short elevation gradient over multiple years (current study and Voelz and others, 2005) showed interpretable relations between urbanization and invertebrate community structure. By contrast, studies collecting samples from several sites along a gradient of urbanization across a short time period showed little relation between urbanization and invertebrate community structure (Sprague and others, 2006) with one exception (Tate and Heiny, 1995). Tate and Heiny (1995) collected samples along an extreme elevation gradient over a short time period and found relations between urban land use and invertebrate community structure. As intended, the Tate and Heiny (1995) study design enhanced the natural differences (for example, elevation) among sites that contributed to the many relations found in that study. Because urbanization and elevation were highly correlated, invertebrate community structure changed with both elevation and urbanization. Although sites in this study were spatially auto-correlated along a relatively short elevation gradient (table 1), an effort was made to remove the natural influence of elevation in the analysis by removing environmental variables that were strongly correlated with elevation. Therefore, these results should represent a clearer picture of the influence of urbanization on invertebrate community structure in the Fountain Creek basin within the bounds of the dataset.

Although little is known about regional historic invertebrate community structure, it is likely that present-day invertebrate communities in Front Range transition zone streams have been truncated to a group of tolerant species by past anthropogenic activities (Zuellig and others, 2007; Zuellig and others, 2006; Kondratieff and Baumann, 2002; Cordeiro, 1999; McCafferty and others, 1993). As with fish, invertebrate communities on the plains are naturally more tolerant than those from less extreme habitats. Surprisingly, even with present-day tolerant taxa dominating all sites in the study by Voelz and others (2005) and the current study, invertebrate communities in Front Range streams apparently were influenced by urbanization through hydrology, habitat, and water chemistry within short urban gradients (tables 1 and 7). These linked relations (for example, urban to hydrology, habitat, and water chemistry to invertebrates) were not apparent in a shorter term study in the South Platte River basin (Sprague and others, 2006). Short-term monitoring of many streams in an ecoregion can sometimes be an effective way to evaluate water quality (Kay and others, 2001; Clements and others, 2000). However, long-term studies provide the necessary background information crucial for separating the differences between natural and anthropogenic changes in water quality (Naiman and others, 1995; Elliott, 1990). Multiple-year studies as opposed to single sampling events across a large number of sites may be needed to better understand the influence of urbanization on stream communities along the Front Range of Colorado. 


\section{Major Findings}

This study demonstrated links between urbanization (impervious surface coverage), stormwater hydrology (maximum daily flow, number of floods, and number of reversals), habitat (percent pool, lower bank capacity, and maximum bank height), water chemistry (dissolved nitrite plus nitrate), and patterns in aquatic community structure in the Fountain Creek basin, 2003 to 2005. Important relations from statistical analyses are summarized in figure 2. Qualitative invertebrate samples collected from all habitat types present at each site (qualitative multihabitat) demonstrated the strongest relation between urban-related environmental variables and patterns in aquatic community structure. Variables related to elevation were removed in order to obtain a better understanding of urban influence on aquatic communities. The strongest and most parsimonious subset of environmental variables describing patterns in QMH invertebrate community structure included high flood pulse count, lower bank capacity, and nitrite plus nitrate (fig. 2, table 7). Several other subsets of environmental variables resulted in competing combinations but always included the three variables found in the most parsimonious subset (table 7).

Semiquantitative invertebrate samples collected from a single habitat type at each site (richest targeted habitat) demonstrated weaker links between patterns in community structure and environmental variables. Patterns in fish community structure were not well explained by the selected urban-related environmental variables addressed in this study. There are likely other environmental variables unrelated to urbanization not evaluated in this report that will better explain RTH invertebrate and fish community structure in the Fountain Creek basin.

Studying the relations between biota and the environment is complex in transition zone streams along the Front Range of Colorado. These ecosystems are influenced by natural gradients as well as by multiple interacting stressors, including urban development, agriculture, and intensive water management. Maintenance or protection of these stream ecosystems

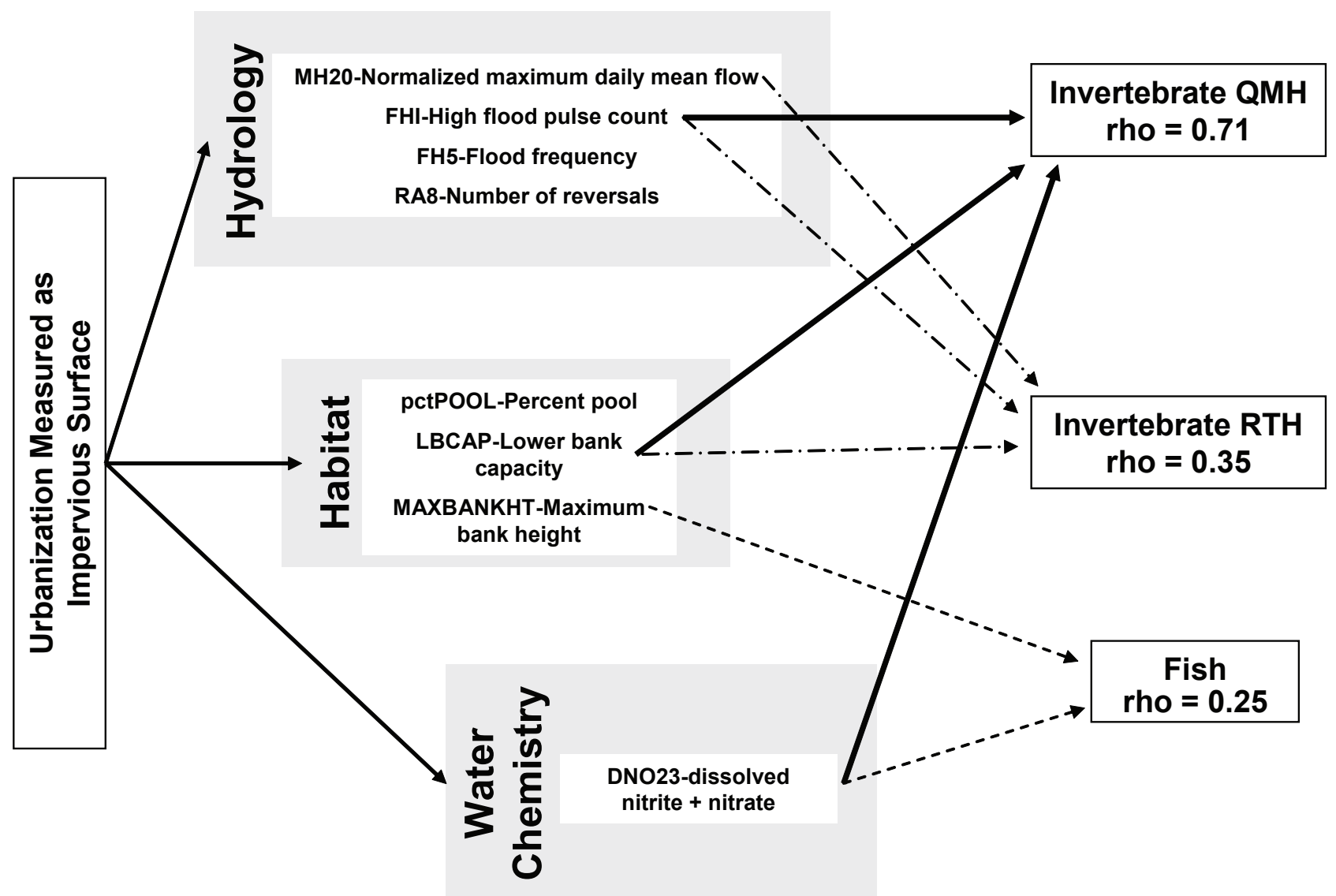

Figure 2. Conceptual model showing the primary urban-related environmental variables associated with stream ecology in the Fountain Creek basin, Colorado. Arrows in the model connecting urbanization to environmental variables represent strong associations between urbanization, hydrology, habitat, and water chemistry found in the correlation analyses (table 6). Arrows connecting environmental variables to invertebrate and fish communities represent the links between environmental variables and patterns in community structure identified with the exploratory multivariate analysis (BIO-ENV procedure) (table 7). Rho values indicate the strength of the match between ordinations of highlighted environmental variables and biological communities. $\mathrm{OMH}$ represents qualitative multihabitat samples and RTH represents richest targeted habitat samples. 
will involve understanding how aquatic communities are structured by natural factors as well as by interacting stressors. Identifying other factors, in addition to urban-related environmental variables found in this study, ultimately will allow better management of stream ecosystems in the face of continued urban development along the Front Range of Colorado.

\section{Summary}

Changes in stream hydrology, geomorphology, water chemistry, water temperature, aquatic communities, and biological processes have been attributed to urbanization. As urbanization occurs the percentage of impervious surfaces in a watershed increases, which decreases the infiltration of precipitation into soils and ultimately leads to increased runoff into streams. Aquatic communities are strongly influenced by the hydrologic regime, physical habitat, and water quality of flowing water, and when these components of stream ecosystems are disturbed, it can adversely affect migration, growth, recruitment, reproduction, competition, and disease progression within aquatic communities.

The influence of urbanization on stream discharge (streamflow), habitat, and aquatic communities is emerging as an issue of importance. Few studies focusing on the influence of urbanization on stream ecology have been conducted in the arid western United States. To address these concerns the USGS, in cooperation with Colorado Springs City Engineering, began a study of the Fountain Creek basin in 2003 to evaluate the influence of urbanization on stream hydrology, habitat, water chemistry, and aquatic communities. This report summarizes previous biological studies from Fountain Creek; evaluates the relations among stream hydrology, environmental characteristics, and biological attributes associated with urbanization in the Fountain Creek basin from 2003 to 2005; and develops a conceptual model of the relations between urban-related environmental variables and biological communities for the Fountain Creek basin.

There are likely 20 fish species native to the Arkansas River basin in Colorado. However, current habitat conditions associated in the Fountain Creek basin likely do not satisfy the species-specific life history requirements for all 20 native fishes. Based on limited historical accounts and basic knowledge on the habitat requirements for the native fishes found in the Arkansas River basin, a conservative estimate of 16 species are likely native to the portion of Fountain Creek basin evaluated in this study. Additionally, there are three state listed species in the Fountain Creek basin: southern redbelly dace (Phoxinus erythrogaster, state endangered), Arkansas darter (Etheostoma cragini, state threatened), and flathead chub (Platygobio gracilis, state species of concern). Very little published information about fish and aquatic invertebrates, or habitat conditions of Fountain Creek, can be found prior to 1982. As a result, little is known about the ecology and distributions of fish and aquatic invertebrates that historically occupied Fountain Creek.

Stream attributes characterized in this study included hydrology, habitat, selected water chemistry, and fish and invertebrate community structure. At each site physical habitat was characterized at the basin-and-reach spatial scales. Land uses in the Fountain Creek basin were used to estimate impervious surface cover. Response of stream hydrology to urbanization was evident among hydrologic variables that described stormwater flow. These indices included one measurement of high-flow magnitude, two measurements of high-flow frequency, and one measurement of stream flashiness. This indicated that the influence of urbanization was associated with stormflow hydrology in the Fountain Creek basin.

A multivariate technique was used to create subsets of environmental variables that best described patterns in fish and invertebrate community structure. Invertebrate community structure was characterized by semi-quantitative richest targeted habitat (RTH) and qualitative multihabitat samples (QMH). The strongest and most parsimonious subset describing patterns in QMH invertebrate community structure included high flood pulse count, lower bank capacity, and nutrients. Several other subsets of environmental variables resulted in competing combinations but always included the three variables found in the most parsimonious subset. This finding indicated that complex relations existed between environmental characteristics and biota, which required multiple types of data (hydrology, habitat, water chemistry) to explain observed patterns in QMH invertebrate community structure. Fish and RTH invertebrate community structure showed weaker links between urban-related environmental variables and biological patterns.

This study found that patterns in fish and invertebrate community structure from the Fountain Creek basin were associated with a variety of environmental characteristics influenced by urbanization. These findings were consistent with some of the effects of urbanization on stream ecology that have been commonly observed by other researchers. A conceptual model was developed that showed the influence of urbanization on environmental variables and their relation to fish and invertebrate assemblages that should help guide future studies. Patterns in invertebrate QMH data were explained by a combination of stream discharge (streamflow), habitat, and water-chemistry variables.

Studying the relations between biota and the environment is complex in transition zone streams along the Front Range of Colorado. These ecosystems are influenced by natural gradients as well as by multiple interacting stressors, including urban development, agriculture, and intensive water management. Maintenance or protection of these stream ecosystems will involve understanding how aquatic communities are structured by natural factors as well as by interacting stressors. Identifying other factors, in addition to urban-related environmental variables found in this study, ultimately will allow better management of stream ecosystems in the face of continued urban development along the Front Range of Colorado. 


\section{References Cited}

Albanese, B., and Matlack, G., 1999, Utilization of parking lots in Hattiesburg, Mississippi, USA, and impacts on local streams: Environmental Management, v. 24, p. 265-271.

Arnold, C.L., and Gibbons, J.C., 1996, Impervious surface coverage-The emergence of a key environmental indicator: Journal of American Planning Association, v. 62, p. 243-258.

Barbour, M.T., Gerritsen, J., Snyder, B.D., and Stribling, J.B., 1997, Revision to rapid bioassessment protocols for use in streams and rivers-Periphyton, benthic macroinvertebrates and fish: U.S. Environmental Protection Agency, Office of Water, Washington, D.C., EPA 841-D-97-002, variously paged.

Bramblett, R.G., and Fausch, K.D., 1991, Variable fish communities and the index of biotic integrity in a western Great Plains River: Transactions of the American Fisheries Society, v. 120, p. 752-769.

Bruce, J.F., 2002, Characterization and analysis of temporal and spatial variations in habitat and macroinvertebrate community structure, Fountain Creek Basin, Colorado Springs and vicinity, Colorado, 1998-2001: U.S. Geological Survey Water-Resources Investigations Report 02-4093, 28 p.

Burton, G.A., Jr., and Pitt, R.E., 2002, Stormwater effects handbook-A toolbox for watershed managers, scientists, and engineers: Boca Raton, Fla., Lewis Publishers, 911 p.

Clarke, K.R., and Ainsworth, M., 1993, A method of linking multivariate community structure to environmental variables: Marine Ecology Progress Series, v. 92, p. 205-219.

Clarke, K.R., and Warwick, R.M., 2001, Change in marine communities: An approach to statistical analysis and interpretation, 2d ed.: Plymouth Marine Laboratory, Plymouth, UK, 172 p.

Clements, W.H., Carlisle, D.M., Lazorchak, J.M., and Johnson, P.C., 2000, Heavy metals structure benthic communities in Colorado mountain streams: Ecological Applications v. 10 , p. 626-638.

Coles, J.F., Cuffney, T.F., McMahon, Gerard, and Beaulieu, K.M., 2004, The effects of urbanization on the biological, physical, and chemical characteristics of coastal New England streams: U.S. Geological Survey Professional Paper 1695, 47 p.

Cordeiro, J.R., 1999, Distribution and habitat of freshwater mussels (Bivalvia: Unionoida: Unionidae) in Colorado: Natural history inventory no. 19, University of Colorado Museum, Boulder, Colorado, 56 p.
Cross, F.B., and Moss, R.E., 1987, Historic changes in fish communities and aquatic habitats in plains streams of Kansas, in Matthews, W.J., and Heins, D.C., eds., Community and evolutionary ecology of North American stream fishes: University of Oklahoma Press, Norman Okla., p. 155-165.

Crowfoot, R.M., Boulger, R.W., Payne, W.F., and O’Neill, G.B., 2003, Water resources data, Colorado, water year 2003, v. 1: U.S. Geological Survey Water-Data Report CO 03-01, 577 p.

Crowfoot, R.M., Payne, W.F., O’Neill, G.B., and Boulger, R.W., 2004, Water resources data, Colorado, water year 2004, v. 1: U.S. Geological Survey Water-Data Report CO 04-01, 344 p.

Crowfoot, R.M., Payne, W.F., O’Neill, G.B., Boulger, R.W., and Sullivan, J.R., 2005, Water resources data, Colorado, water year 2005 .

Cuffney, T.F., 2003, User's manual for the National WaterQuality Assessment Program invertebrate data analysis system (IDAS) software-Version 3: U.S. Geological Survey Open-File Report 03-172, 103 p.

Dunne, T., and Leopold, L.B., 1978, Water in Environmental Planning: New York, W.H. Freeman and Company, 817 p.

Edelmann, P., Ferguson, S.A., Stogner, R.W., Sr., August, M., Payne, W.F., and Bruce, J.F., 2002, Evaluation of water quality, suspended sediment, and stream morphology with an emphasis on effects of storm flow on Fountain and Monument Creek basins, Colorado Springs and vicinity, Colorado, 1981 through 2001: U.S. Geological Survey Water-Resources Investigations Report 02-4104, 59 p.

Edmunds, G.F., and McCafferty, W.P., 1984, Ephemera compar-An obscure Colorado burrowing mayfly (Ephemeroptera: Ephemeridae): Entomological News, v. 95, p.186-188.

Edwards, T.K., and Glysson, G.D., 1988, Field methods for measurement of fluvial sediment: U.S. Geological Survey Open-File Report 86-531, 117 p.

Elliott, J.M., 1990, The need for long-term investigations in ecology and the contribution of the Freshwater Biological Association: Freshwater Biology, v. 23, p. 1-5.

Everitt, B.S., 2002, The Cambridge Dictionary of Statistics, 2d ed.: New York, Cambridge University Press, p. 410.

Fausch, K.D., and Bestgen, K.R., 1997, Ecology of fishes indigenous to the central and southwestern Great Plains, in Knopf, F.L., and Samson, F.B., eds., Ecology and conservation of Great Plains vertebrates: New York, Springer-Verlag, Inc., p. 131-166. 
Fishman, M.J., 1993, Methods of analysis by the U.S. Geological Survey National Water Quality Laboratory-Determination of inorganic and organic constituents in water and fluvial sediments: U.S. Geological Survey Open-File Report 93-125, 217 p.

Fitzgerald, D.G., Lanno, R.P., and Dixon, D.G., 1999, A comparison of a sentinel species evaluation using creek chub (Semotilus atromaculatus Mithcill) to a fish community evaluation for the initial identification of environmental stressors in small streams: Ecotoxicology, v. 8, p. 33-48.

Guy, H.P., 1969, Laboratory theory and methods for sediment analysis: U.S. Geological Survey Techniques of WaterResources Investigations, book 5, chap. C1, 58 p.

Hansen, W.R., and Crosby, E.J., 1982, Environmental geology of the Front Range urban corridor and vicinity, Colorado with a specific section on Physical properties and performance characteristics of surficial deposits and rock units in the greater Denver area by R.R. Shroba: U.S. Geological Survey Professional Paper 1230, 99 p.

Henriksen, J.A., Heasley, J., Kennen, J.G., and Nieswand, S., 2006, Users' manual for the hydroecological integrity assessment process software (including the New Jersey assessment tools), Fort Collins, Colo.: U.S. Geological Survey, Fort Collins Science Center, Open-File Report 2006-1093, 71 p.

Hirsch, R.M., Walker, J.F., Day, J.C., and Kallio, R., 1990, The influence of man on hydrologic systems, in Wolaman, M.G., and Riggs, H.C., eds., Surface water hydrology: Boulder, Colo., Geological Society of America, p. 329-359.

House, M.A., Ellis, J.B., Herricks, E.E., Hvitved-Jacobsen, T., Seager, J., Lijklema, L., Aaldernik, H., and Clifforde, I.T., 1993, Urban drainage-Impacts on receiving water quality: Water Science and Technology, v. 27, p. 117-158.

Jones, R.C., and Clark, C.C., 1987, Impact of watershed urbanization on stream insect communities: Water Resources Bulletin, v. 23, p. 1047-1055.

Kay, W.R., Halse, S.A., Scanlon, M.D., and Smith, M.J., 2001, Distribution and environmental tolerances of aquatic macroinvertebrate families in the agricultural zone of southwestern Australia: Journal of the North American Benthological Society, v. 20, p. 182-199.

Kennen, J.G., 1999, Relation of invertebrate community impairment to catchment characteristics in New Jersey streams: Journal of the American Water Resources Association, v. 35, p. 939-954.

Kennen, J.G., and Ayers, M.A., 2002, Relation of environmental characteristics to the composition of aquatic assemblages along a gradient of urban land use in New Jersey, 1996-1998: U.S. Geological Survey Water-Resources Investigations Report 02-4069, 77 p.
Klein, R.D., 1979, Urbanization and stream quality impairment: Water Resources Bulletin, v. 15, p. 948-963.

Knighton, D., 1998, Fluvial forms and processes-A new perspective: New York, John Wiley and Sons, 383 p.

Kolpin, D.W., Furlong, E.T., Meyer, M.T., Thurman, E.M., Zaugg, S.D., Barber, L.B., and Buxton, H.T., 2002, Pharmaceuticals, hormones, and other organic wastewater contaminants in United States streams, 1999-2000_A national reconnaissance: Environmental Science and Technology, v. 36, no. 6, p. 1202-1211.

Kondratieff, B.C., and Baumann, R.W., 2002, A review of the stoneflies of Colorado with description of a new species of Capnia (Plecoptera: Capniidae): Transactions of the American Entomological Society, v. 128, p. 385-401.

Konrad, C.P., and Booth, D.B., 2005, Hydrologic changes in urban streams and their ecological significance: American Fisheries Society Symposium, v. 47, p. 157-177.

Larsen, L.S., 1981, Soil survey of El Paso County area, Colorado: Washington, D.C.: U.S. Department of Agriculture, Soil Conservation Service, 212 p.

LeBlanc, R.T., Brown, R.D., and FitzGibbon, J.E., 1997, Modeling the effects of land use change on water temperature in unregulated urban streams: Journal of Environmental Management, v. 49, p. 445-469.

Leopold, L.B., 1968, Hydrology for urban land planning-A guidebook on the hydrologic effects of urban land uses: Washington, D.C., U.S. Geological Survey Circular 554, $10 \mathrm{p}$.

Loeffler, C., Miller, R., and Krieger, D.A., 1982, Arkansas River threatened fishes survey, Performance Report, Federal Aid Project SE-8-1-2: Colorado Division of Wildlife, 8 p. + 4 Appendixes.

Long, J., and Schorr, M.S., 2005, Effects of watershed urban land use on environmental conditions and fish assemblages in Chattanooga area streams (Tennessee-Georgia): Journal of Freshwater Ecology, v. 20, p. 527-537.

Mathsoft, Inc., 2000, S-Plus 2000 Professional-Release 3: Mathsoft Inc. [CD-ROM].

Matthaei, C.D., Peacock, K.A., and Townsend, C.R., 1999, Scour and fill patterns in a New Zealand stream and potential implications for invertebrate refugia: v. 42, no. 1, p. 41-57.

Matthews, W.J., 1986, Physicochemical tolerance and selectivity of stream fishes as related to their geographic ranges and local distributions, in Matthews, W.J., and Heins, D.C., eds., Community and evolutionary ecology of North American stream fishes: Norman, Okla., University of Oklahoma Press, p. 111-120. 
Mau, D.P., Stogner, R.W., Sr., Edelman, P., 2007, Evaluation of storm flows and waste-water treatment plant effluent discharges on water quality, suspended sediment, and channel morphology for Monument and Fountain Creek watersheds, Colorado, 1981-2006: U.S. Geological Survey Scientific Investigations Report 07-5104, 76 p.

McCafferty, W.P., Durfee, R.S., and Kondratieff, B.C., 1993, Colorado mayflies (Ephemeroptera) - An annotated inventory: The Southwestern Naturalist, v. 38, p. 252-274.

McMahon, G., Bales, J.D., Coles, J.F., Giddings, E.M.P., and Zappia, H., 2003, Use of stage data to characterize hydrologic conditions in an urbanizing environment: Journal of the American Water Resources Association, v. 39, p. 1529-1546.

McMurry, L.M., Oethinger, M., and Levy, S.B., 1998, Overexpression of marA, soxS, or acrAB produces resistance to triclosan in laboratory and clinical strains of Escherichia coli: FEMS Microbiology Letters, v. 166, no. 2, p. 305-309.

Meador, M.R., Hupp, C.R., Cuffney, T.F., and Gurtz, M.E., 1993, Methods for characterizing stream habitat as part of the National Water-Quality Assessment Program: U.S. Geological Survey Open-File Report 93-408, 48 p.

Morgan, R.P., and Cushman, S.F., 2005, Urbanization effects on stream fish assemblages in Maryland, USA: Journal of the North American Benthological Society, v. 24, p. 643-655.

Moulton, S.R., II, Carter, J.L., Grotheer, S.A., Cuffney, T.F., and Short, T.M., 2000, Methods of analysis by the U.S. Geological Survey National Water-Quality LaboratoryProcessing, taxonomy, and quality control of invertebrate samples: U.S. Geological Survey Open-File Report 02-212, 49 p.

Nadler, C.T., and Schumm, S.A., 1981, Metamorphosis of South Platte and Arkansas Rivers, eastern Colorado: Physical Geography, v. 2, p. 95-115.

Naiman, R.J., Magnuson, J.J., McKnight, D.M., and Stanford, J.A., 1995, The freshwater imperative, a research agenda: Island Press, Washington, D.C.

Nesler, T.P., Bennett, C., Melby, J., Dowler, G., and Jones, M., 1999, Inventory and status of Arkansas River native fishes in Colorado: Colorado Division of Wildlife, Final Report, $120 \mathrm{p}$.

Olden, J.D., and Poff, N.L., 2003, Redundancy and choice of hydrologic indices for characterizing streamflow regimes:

River Research and Applications, v. 19, p. 101-121.

Omernik, J.M., 1987, Ecoregions of the conterminous United States: Annals of the Association of American Geographers, v. 77 , p. 118-125.
Orth, D.J., 1983, Aquatic habitat measurements, in Nielsen, L.A., and Johnson, D.L., eds., Fisheries techniques, Chapter 4: Bethesda, Md., American Fisheries Society, p. 61-84.

Paul, M.J., and Meyer, J.L., 2001, Streams in the urban landscape: Annual Review of Ecology and Systematics, v. 32, p. 333-365.

Pikes Peak Area Council of Governments, 2005, Fountain Creek watershed, impervious surface area and watershed health analysis, accessed October 3, 2006, at http://www. fountain-crk.org/Reports/impervious\%20surface\%20report. htm

Pitt, R.E., Field, R., Lalor, M., and Brown, M., 1995, Urban stormwater toxic pollutants-Assessment, sources, and treatability: Water Environment Research, v. 67, p. 260-275.

Pizzuto, J.E., Hession, W.C., McBride, M., 2000, Comparing gravel-bed rivers in paired urban and rural catchments of southeastern Pennsylvania: Geology, v. 28, p. 79-82.

Poff, N.L., Allan, J.D., Bain, M.B., Karr, J.R., Prestegaard, K.L., Richter, B.D., Sparks, R.E., and Stromberg, J.C., 1997, The natural flow regime-A paradigm for river conservation and restoration: Bioscience, v. 47, p. 769-784.

Pusey, B.J., Kennard, M.J., Arthur, J.M., and Arthington, A.H., 1998, Quantitative sampling of stream fish assemblages: Single- vs. multiple-pass electrofishing: Australian Journal of Ecology, v. 23, p. 365-374.

Rahel, F.J., Hubert, W.A., 1991, Fish assemblages and habitat gradients in a Rocky Mountain Great-Plains stream-Biotic zonation and additive patterns of community change: Transactions of the American Fisheries Society, v. 120, p. 319-332.

Rantz, S.E., and others, 1982, Measurement and computation of streamflow-Volume 2. Computation of discharge: U.S. Geological Survey Water-Supply Paper 2175, 347 p.

Riordan, E.J., Griggs, N.S., Hiller, R.L., 1978, Measuring the effects of urbanization on the hydrologic regime, in Conference on International Symposium on Urban Drainage, $1^{\text {st }}$, Southampton, UK., 1978, Proceedings: American Society of Civil Engineers, p. 496-511.

Roy, A.H., Rosemond, A.D., Paul, M.J., Leigh, D.S., and Wallace, J.B., 2003, Stream macroinvertebrate response to catchment urbanization (Georgia, U.S.A.): Freshwater Biology, v. 48, p. 329-346.

Roy, A.H., Freeman, M.C., Freeman, B.J., Wenger, S.J., Ensign, W.E., and Meyer, J.L., 2005, Investigating hydrologic alteration as a mechanism of fish assemblage shifts in urbanizing streams: Journal of the North American Benthological Society, v. 24, p. 656-678. 
Schrader, L.H., 1989, Use of the index of biotic integrity to evaluate fish communities in Western Great Plains streams: Masters Thesis, Colorado State University, Fort Collins, Colorado, $120 \mathrm{p}$.

Schreurs, R.M., Legler, J., Artola-Garicano, E., Sinnige, T.L., Lanser, P.H., Seinen, W., and Van Der Burg, B., 2004, In vitro and in vivo antiestrogenic effects of polycyclic musks in zebrafish: Environmental Science and Technology, v. 38, no. 4, p. 997-1002.

Short, T.M., Giddings, E.M., Zappia, H., and Coles, J.F., 2005, Urbanization effects on stream habitat characteristics in Boston, Massachusetts; Birmingham, Alabama; and Salt Lake City, Utah, in Brown, L.R., Gray, R.H., Hudges, R.M., and Meador, M.R., eds., Effects of urbanization on stream ecosystems: American Fisheries Society, Symposium 47, Bethesda, Maryland, p. 317-332.

Sprague, L.A., Zuellig, R.E., Dupree, J.A., 2006, Effects of urbanization on stream ecosystems in the South Platte River Basin, Colorado and Wyoming: U.S. Geological Survey Scientific Investigations Report 2006-5101-A, 141 p.

Stogner, R.W., Sr., 2000, Trends in precipitation and streamflow and changes in stream morphology in the Fountain Creek watershed, Colorado, 1939-99: U.S. Geological Survey Water-Resources Investigations Report 00-4130, 43 p.

Tate, C.M., and Heiny, J.S., 1995, The ordination of benthic invertebrate communities in the South Platte River Basin in relation to environmental factors: Freshwater Biology, v. 33, p. $439-454$.

Thorpe, K.L., Hutchinson, T.H., Hetheridge, M.J., Scholze, M., Sumpter, J.P., and Tyler, C.R., 2001, Assessing the biological potency of binary mixtures of environmental estrogens using vitellogenin induction in juvenile rainbow trout (Oncorhynchus mykiss): Environmental Science and Technology, v. 35, no. 12, p. 2476-2481.

U.S. Environmental Protection Agency, 2000, The quality of our nation's waters: EPA Report 841-S-00-001.

U.S. Geological Survey, variously dated, National field manual for the collection of water-quality data: U.S. Geological Survey Techniques of Water-Resources Investigations, book 9, chaps. A1-A9, available online at http://pubs.water.usgs. gov/twrigA

U.S. Geological Survey, 1974, Northeast Pueblo, Colo. quadrangle and Pinon, Colo. quadrangle: 1:24,000-scale.
Voelz, N.J., Zuellig, R.E., Shieh, Sen-Her, and Ward, J.V., 2005, The effects of urban areas on benthic invertebrates in two Colorado plains rivers: Environmental Monitoring and Assessment, v. 101, p. 175-202.

von Guerard, Paul, 1989, Sediment-transport characteristics and effects of sediment transport on benthic invertebrates in the Fountain Creek drainage basin upstream from Widefield, southeastern Colorado 1985-88: U.S. Geological Survey Water-Resources Investigations Report 88-4161, $133 \mathrm{p}$.

Walsh, C.J., Roy, A.H., Feminella, J.W., Cottingham, P.D., Groffman, P.M., Morgan, R.P., 2005, The urban stream syndrome: Current knowledge and the search for a cure: Journal of the North American Benthological Society, v. 24, p. 706-723.

Wang, L.Z., Lyons, J., and Kanehl, P., 1997, Impacts of urbanization on stream habitat and fish across multiple spatial scales: Environmental Management, v. 28, p. 255-266.

Ward, J.V., 1986, Altitudinal zonation in a Rocky Mountain stream: Archiv f. Hydrobiologie, Supplement 74, v. 2, p. 133-199.

Waters, T.F., 1995, Sediment in streams-Sources, biological effects and control: American Fisheries Society Monograph 7, $249 \mathrm{p}$.

Wolman, M.G., 1954, A method for sampling coarse riverbed material: Transactions of the American Geophysical Union, v. 35 , p. $951-956$.

Wood, P.J., and Armitage, P.D., 1997, Biological effects of fine sediment in the lotic environment: Environmental Management, v. 21, no. 2, p. 203-217.

Zuellig, R.E., Sprague, L.A., Collins, J.A., Cox, O.N., 2007, Aquatic communities and selected water chemistry in St. Vrain Creek near the City of Longmont, Colorado, wastewater-treatment plant, 2005 and 2006: U.S. Geological Survey Data Series 253, $30 \mathrm{p}$.

Zuellig, R.E., Kondratieff, B.C., and Hood, R.W., 2006, Studies on stoneflies (Plecoptera) of Colorado with eastern faunal affinities, including a new state record of the midwestern salmonfly, Pteronarcys pictetii Hagen (Plecoptera: Pteronarcyidae): Proceedings of the Entomological Society of Washington, v. 108, p. 335-340. 


\section{Glossary}

anthropogenic Occurring because of, or influenced by, human activity.

base flow Sustained flow in a stream; ground-water discharge is the source of base flow in most streams.

Bray-Curtis Similarity A measure of similarity (city-block distance) between two samples based on the number and frequency of taxa (variables).

channelization Modification of a stream, typically by straightening the channel, to provide more uniform flow.

confluence The location where a tributary joins the main stream.

drainage basin The portion of the surface of a geographic area that contributes water to a stream through overland runoff.

ecological studies Studies of biological communities and habitat characteristics to evaluate the influence or effects of physical and chemical characteristics of water and hydrologic conditions on aquatic biota.

ecoregion An area of similar climate, landform, soil, potential natural vegetation, hydrology, or other ecologically relevant variable.

Euclidean distance A measure of the linear distance between two samples in multidimensional space.

geomorphic channel units Fluvial geomorphic descriptors of channel shape and stream velocity. Pool, riffles, and runs are three types of geomorphic channel units.

habitat In general, aquatic habitat includes all nonliving (physical) attributes of the aquatic ecosystem (Orth, 1983), although living components like aquatic macrophytes and riparian vegetation are also included.

ichthyofauna Pertains to fish, and fishes found in a region.

loess A method of regression analysis (Locally Weighted Regression) in which polynomials are used to approximate the regression function. Often used for smoothing scatter diagrams to allow any structure to be seen more clearly and for identifying possible nonlinear relationships (Everitt, 2002).

lithophilic spawner A fish species that requires gravel or cobble for nest construction and successful spawning. percid A fish species belonging to the perch family (Percidae).

pool A relatively small portion of a stream reach with little velocity, commonly with water deeper than surrounding areas.

qualitative multihabitat (OMH) Different habitats identified in a reach from which fish and invertebrate samples are collected.

reach A length of stream that is chosen to represent a uniform set of physical, chemical, and biological conditions. It is the principal sampling unit for collecting physical, chemical, and biological data.

richest targeted habitat (RTH) A targeted habitat, where the taxonomically richest invertebrate community is theoreticallylocated, and where invertebrate samples are collected.

riffle A shallow part of the stream where water flows swiftly over completely or partially submerged coarse substrate that produces turbulence of the water surface which enhances aeration.

run A relatively shallow part of a stream with moderate velocity and little or no surface turbulence.

stage The height of a water surface above an established datum; same as gage height.

stormwater runoff Rainwater or snowmelt that is transported to streams by overland flow or drains.

transect A line across a stream perpendicular to the flow and along which measurements are made, so that morphological and flow characteristics along the line are described bank to bank.

trophic guild Group of species that prey or forage on the same food resources.

voucher collection An assortment of preserved specimens representing the fauna that was sampled. It is used for validating taxonomic identifications and documenting spatial and temporal distribution and variation.

wadeable A stream that can be safely waded while effectively using sampling equipment. 
